\title{
A synthesis of the Antarctic surface mass balance during the last $800 \mathrm{yr}$
}

\author{
M. Frezzotti ${ }^{1}$, C. Scarchilli ${ }^{1}$, S. Becagli ${ }^{2}$, M. Proposito ${ }^{1}$, and S. Urbini ${ }^{3}$ \\ ${ }^{1}$ ENEA, Agenzia Nazionale per le nuove tecnologie, l'energia e lo sviluppo sostenibile, Rome, Italy \\ ${ }^{2}$ Department of Chemistry, University of Florence, Sesto F.no, Italy \\ ${ }^{3}$ INGV, Istituto Nazionale di Geofisica e Vulcanologia,, Rome, Italy
}

Correspondence to: M. Frezzotti (massimo.frezzotti@enea.it)

Received: 27 December 2011 - Published in The Cryosphere Discuss.: 22 February 2012

Revised: 23 January 2013 - Accepted: 23 January 2013 - Published: 20 February 2013

\begin{abstract}
Global climate models suggest that Antarctic snowfall should increase in a warming climate and mitigate rises in the sea level. Several processes affect surface mass balance (SMB), introducing large uncertainties in past, present and future ice sheet mass balance. To provide an extended perspective on the past SMB of Antarctica, we used 67 firn/ice core records to reconstruct the temporal variability in the SMB over the past $800 \mathrm{yr}$ and, in greater detail, over the last $200 \mathrm{yr}$.

Our SMB reconstructions indicate that the SMB changes over most of Antarctica are statistically negligible and that the current SMB is not exceptionally high compared to the last $800 \mathrm{yr}$. High-accumulation periods have occurred in the past, specifically during the 1370 s and 1610s. However, a clear increase in accumulation of more than $10 \%$ has occurred in high SMB coastal regions and over the highest part of the East Antarctic ice divide since the 1960s. To explain the differences in behaviour between the coastal/ice divide sites and the rest of Antarctica, we suggest that a higher frequency of blocking anticyclones increases the precipitation at coastal sites, leading to the advection of moist air in the highest areas, whereas blowing snow and/or erosion have significant negative impacts on the SMB at windy sites. Eight hundred years of stacked records of the SMB mimic the total solar irradiance during the 13th and 18th centuries. The link between those two variables is probably indirect and linked to a teleconnection in atmospheric circulation that forces complex feedback between the tropical Pacific and Antarctica via the generation and propagation of a large-scale atmospheric wave train.
\end{abstract}

\section{Introduction}

The rise in global mean sea level is one of the major longterm consequences of climate change. Determining the future contribution of the Antarctic Ice Sheet (AIS) to the global sea level rise is likely to be a complex task. The AIS constantly adjusts its mass in response to changes in snow accumulation on its surface. These changes occur on annual to millennial time scales, with a concomitant effect on global sea levels.

The surface mass balance (SMB) results from precipitation in the form of snow (snowfall and diamond dust/clearsky precipitation), which is then modified by surface sublimation, the erosion/deposition of snowdrift transport, the sublimation of drifting/blowing snow particles (wind-driven sublimation) and melting. Wind erosion, wind redistribution and sublimation as well as other processes during or after a precipitation event lead to deposition at the surface that is spatially much less homogeneous than the original precipitation (e.g., Eisen et al., 2008).

The SMB of the grounded AIS is approximately $2100 \mathrm{Gt} \mathrm{yr}^{-1}$, with a large interannual variability. Those changes can be as large as $300 \mathrm{Gt} \mathrm{yr}^{-1}$ and represent approximately 6\% of the 1989-2009 average (Van den Broeke et al., 2011). Moreover, although modern altimetry and gravimetric technologies are strongly improving the possibilities for mass balance detection, the SMB uncertainty is estimated to be more than $10 \%$ (equivalent to nearly $0.6 \mathrm{~mm} \mathrm{yr}^{-1}$ of sea level rise), which is at least equal to the ice discharge uncertainty (Frezzotti et al., 2007; Magand et al., 2007). 
Climate model projections based on increasing greenhouse gas concentrations predict a warmer atmosphere containing higher levels of water vapour, suggesting that the Antarctic snowfall is expected to increase. Thus, the SMB of the AIS will negatively contribute to sea level rise (Monaghan et al., 2008; Gregory and Huybrechts, 2006; Krinner et al., 2007; Uotila et al., 2007). However, snow precipitation reflects not only air temperature/warmer atmosphere variations, but also conditions at the ocean surface, the atmospheric teleconnection, and circulation patterns. Approximately $75 \%$ of the predicted precipitation increase will fall in peripheral areas with surface elevations below $2250 \mathrm{~m}$ (Genthon et al., 2009). Recent satellite observations indicate an accelerating ice loss in these peripheral areas due to ongoing and past glacier acceleration, implying that the contribution of ice sheets to sea level rise increases over time (Velicogna, 2009; Rignot et al., 2008; Pritchard et al., 2009).

Information on the temporal and spatial variability of the SMB is essential for determining the input term of the mass balance (component approach: SMB minus ice discharge at the grounding line), but also for interpreting the surface elevation/mass change signals from satellites (integrated approach, elevation, or mass change) and making improvements in climate and meteorological models (ISMASS Committee, 2004).

The combination of satellite-derived temperature data with meteorological observations reveals a significant increase of near-surface temperatures across the Antarctic Peninsula (AP) and, to a lesser extent, in the West Antarctic Ice Sheet (WAIS) since the early 1950s, with minimal changes across the rest of the East Antarctic Ice Sheet (EAIS, Steig et al., 2009). The warming rate since the 1950 s has been approximately $0.080^{\circ} \mathrm{C}$ per decade, which is considered as the mean value for all of Antarctica (Chapman and Walsh, 2007; Steig et al., 2009). However, the magnitude and significance of the temperature trends in Antarctica is still a debated issue, and the results are highly dependent on seasons and their periodicity. In the troposphere above the surface of Antarctica, a fairly strong winter (June-July-August) warming has occurred since the early 1970s (Turner et al., 2006). Much of Antarctica receives its maximum snowfall in winter (Marshall, 2009). There is evidence of a warming and freshening trend in the waters of the Southern Ocean and a reduction of the sea ice extent during the 1950s and 1960s (Curran et al., 2003; Abram et al., 2010). However, firn cores coupled with an atmospheric reanalysis model of the AIS indicate statistically insignificant or slightly negative SMB changes in the AIS since the 1950s (Monaghan et al., 2006). SMB research based on firn/ice core records from recent decades reveals a variety of changes and trends, ranging from slight increases (Thompson et al., 1994; Morgan et al., 1991; MosleyThompson et al., 1999; Frezzotti et al., 2005; Goodwin et al., 2003; Stenni et al., 2002; Urbini et al., 2008; Igarashi et al., 2011; Fujita et al., 2011) to doublings (Thomas et al., 2008), to decreases (Spikes et al., 2004; Kaspari et al., 2004;
Schlosser and Oerter, 2002; Kaczmarska et al., 2004; Ren et al., 1999), or to no significant trend in the SMB (Frezzotti et al., 2007; Ruth et al., 2004; Anschütz et al., 2009, 2011; Sommer et al., 2000; Karlöf et al., 2005; Stenni et al., 1999).

The main purpose of this study is to evaluate how the SMB has affected the mass of the AIS at the centennial scale and to provide an extended past perspective. For this purpose, we used seven new firn/ice records from northern Victoria Land and Wilkes Land (WILKES) together with the 60 existing firn/ice records to reconstruct the temporal variability of the SMB over the past $800 \mathrm{yr}$ and, in greater detail, over the last $200 \mathrm{yr}$. In Sect. 2, we describe the various methods applied to evaluate the SMB values and its temporal variability from firn and ice core measurements. In Sect. 3, we present the results obtained by comparing the average SMB values in three different time windows, namely, the last $40 \mathrm{yr}$, the last $150 \mathrm{yr}$, and the last $800 \mathrm{yr}$, to elucidate the temporal and spatial variability of the SMB at the continental and regional scales. Finally, in Sect. 4, we discuss the possible causes of the SMB temporal variability and spatial distribution.

\section{Data and methods}

The available dataset (67 records; Fig. 1; Table 1) spans one century and is spatially representative of the entire Antarctic continent, with approximately 3 records in the AP, 14 records in the WAIS, and the other records in the EAIS. SMB time series records exist for the WAIS that extend more than $500 \mathrm{yr}$, and four and two records are available for the Dronning Maud Land (DML) and WILKES, respectively, that extend back further than $800 \mathrm{yr}$.

The SMB temporal variability is evaluated in firn and ice cores (from annual to centennial scales) by counting the seasonal cycles of various parameters (physical, chemical and isotopic) and by identifying prominent horizons of known ages, such as the fallout of acid layers from dated volcanic eruptions (e.g., 1964, Agung; 1887, Krakatua; 1816-1809, Tambora-Unknown; 1601, Huaynaputina; 1460, Kuwae; and 1259, Unknown) or radioactive fallout (e.g., 1955 and 1966) from atmospheric thermonuclear bomb tests (Eisen et al., 2008). Most recently, the SMB has been evaluated at selected sites using stake farms (Frezzotti et al., 2007; Urbini et al., 2008; Kameda et al., 2008; Ding et al., 2011a). In general, however, seasonal cycles are difficult to observe at sites with low accumulations (below approximately $70 \mathrm{~kg} \mathrm{~m}^{-2} \mathrm{yr}^{-1}$ ), such as the polar plateau of the EAIS and windy sites, because the seasonally deposited chemical or physical signals are frequently erased or changed by the action of the nearsurface wind (Eisen et al., 2008). In the entire record, the two most valid reference horizons in the 1960s (the atomic bomb and Agung eruption reference layers), the TamboraUnknown volcanic eruptions at the beginning of the 19th century and the oldest dated volcanic eruptions (e.g., 1460, Kuwae eruption; and 1259, Unknown eruption) are used 
Table 1. Site information and snow accumulation values.

\begin{tabular}{|c|c|c|c|c|c|c|c|c|}
\hline Site name & $\begin{array}{l}\text { Latitude } \\
\left({ }^{\circ}\right)\end{array}$ & $\begin{array}{l}\text { Longitude } \\
\left({ }^{\circ}\right)\end{array}$ & $\begin{array}{l}\text { Elevation } \\
(\mathrm{m})\end{array}$ & $\begin{array}{l}\text { Entire Record } \\
\left(\mathrm{kg} \mathrm{m}^{-2} \mathrm{yr}^{-1}\right)\end{array}$ & $\begin{array}{l}\text { Tambora- present } \\
\left(\mathrm{kg} \mathrm{m}^{-2} \mathrm{yr}^{-1}\right)\end{array}$ & $\begin{array}{l}1960 \mathrm{~s}- \\
\text { present } \\
\left(\mathrm{kg} \mathrm{m}^{-2} \mathrm{yr}^{-1}\right)\end{array}$ & $\begin{array}{l}\text { Present } \\
\left(\mathrm{kg} \mathrm{m}^{-2} \mathrm{yr}^{-1}\right)\end{array}$ & References \\
\hline $\begin{array}{l}\text { SIPLE DOME } \\
\left(\Omega, \Omega_{\text {TIME }}\right)\end{array}$ & 81.65 & -149.00 & 620 & $\begin{array}{l}120 \\
(1890-1994)\end{array}$ & & $\begin{array}{l}118 \\
(1922-91)\end{array}$ & & Kaspari et al. (2004) \\
\hline $\begin{array}{l}\text { ITASE00-5 } \\
\left(\Omega, \Omega_{\text {TIME }}\right)\end{array}$ & 77.68 & -124.00 & 1828 & $\begin{array}{l}140 \\
(1716-2000)\end{array}$ & & $\begin{array}{l}141 \\
(1922-91)\end{array}$ & & $\begin{array}{l}\text { Kaspari et al. (2004); } \\
\text { Spike et al. (2004) }\end{array}$ \\
\hline $\begin{array}{l}\text { ITASE99-1 } \\
(\Omega, \Omega \text { TIME })\end{array}$ & 80.62 & -122.63 & 1350 & $\begin{array}{l}139 \\
(1724-1998)\end{array}$ & & $\begin{array}{l}146 \\
(1922-91)\end{array}$ & & Kaspari et al. (2004) \\
\hline $\begin{array}{l}\text { ITASE00-4 } \\
\left(\Omega, \Omega_{\mathrm{TIME}}\right)\end{array}$ & 78.08 & -120.08 & 1697 & $\begin{array}{l}189 \\
(1799-2000)\end{array}$ & & $\begin{array}{l}193 \\
(1922-91)\end{array}$ & & $\begin{array}{l}\text { Kaspari et al. (2004); } \\
\text { Spike et al. (2004) }\end{array}$ \\
\hline $\begin{array}{l}\text { RIDS A } \\
\left(\Omega, \Omega_{\mathrm{TIME}}\right)\end{array}$ & 78.73 & -116.33 & 1740 & $\begin{array}{l}235 \\
(1831-1995)\end{array}$ & & $\begin{array}{l}234 \\
(1922-91)\end{array}$ & & Kaspari et al. (2004) \\
\hline $\begin{array}{l}\text { WDC05A } \\
\left(\Omega, \Omega_{\mathrm{TIME}}\right)\end{array}$ & 79.46 & -112.13 & 1759 & $\begin{array}{l}200 \pm 34 \\
(1775-2005)\end{array}$ & & & & Banta et al. (2008) \\
\hline $\begin{array}{l}\text { WDC05Q } \\
\left(\Omega, \Omega_{\mathrm{TIME}}\right)\end{array}$ & 79.47 & -112.09 & 1759 & $\begin{array}{l}204 \pm 35 \\
(1521-2005)\end{array}$ & & & & Banta et al. (2008) \\
\hline $\begin{array}{l}\text { ITASE00-1 } \\
\left(\Omega, \Omega_{\text {TIME }}\right)\end{array}$ & 79.38 & -111.24 & 1791 & $\begin{array}{l}220 \\
(1653-2001)\end{array}$ & & $\begin{array}{l}222 \\
(1922-91)\end{array}$ & & Kaspari et al. (2004) \\
\hline ITASE01-2 & 77.84 & -102.91 & 1353 & $\begin{array}{l}427 \\
(1890-2001)\end{array}$ & & $\begin{array}{l}436 \\
(1922-91)\end{array}$ & & Kaspari et al. (2004) \\
\hline $\begin{array}{l}\text { ITASE01-3 } \\
\left(\Omega, \Omega_{\mathrm{TIME}}\right)\end{array}$ & 78.12 & -95.65 & 1633 & $\begin{array}{l}325 \\
(1859-2001)\end{array}$ & & $\begin{array}{l}331 \\
(1922-91)\end{array}$ & & Kaspari et al. (2004) \\
\hline $\begin{array}{l}\text { ITASE } 1-5 \\
\left(\Omega, \Omega_{\text {TIME }}\right)\end{array}$ & 77.06 & -89.14 & 1246 & $\begin{array}{l}388 \\
(1780-2001)\end{array}$ & & $\begin{array}{l}342 \\
(1922-91)\end{array}$ & & Kaspari et al. (2004) \\
\hline GOMEZ & 73.59 & -70.36 & 1400 & $\begin{array}{l}720 \\
(1855-2006)\end{array}$ & $\begin{array}{l}655 \\
(1855-1970 \mathrm{~s})\end{array}$ & $\begin{array}{l}925 \\
(1970 s-2006)\end{array}$ & & Thomas et al. (2008) \\
\hline $\begin{array}{l}\text { DRYER PLATEAU } \\
(\Omega)\end{array}$ & 70.67 & -64.89 & 2002 & $\begin{array}{l}440 \\
(1500-1989)\end{array}$ & $460 \mathrm{ie}^{\mathrm{a}}$ & $540 \mathrm{ie}^{\mathrm{a}}$ & & $\begin{array}{l}\text { Thompson et al. (1994); } \\
\text { Raymond et al. (1996) }\end{array}$ \\
\hline $\begin{array}{l}\text { JAMES ROSS } \\
\text { ISLAND } \\
(\Omega)\end{array}$ & 64.22 & -57.68 & 1640 & & $\begin{array}{l}443 \\
(1847-1980)\end{array}$ & $\begin{array}{l}578 \\
(1964-1990)\end{array}$ & & Aristarain et al. (2004) \\
\hline $\begin{array}{l}\text { BERKNER } \\
\text { B25 } \\
\left(\Omega, \Omega_{\mathrm{TIME}}\right)\end{array}$ & 79.57 & -45.72 & 890 & $\begin{array}{l}130 \pm 40 \\
(1080-1994)\end{array}$ & $\begin{array}{l}131 \\
(1815-1965)\end{array}$ & $\begin{array}{l}141 \\
(1965-1994)\end{array}$ & & Ruth et al. (2004) \\
\hline $\begin{array}{l}\mathrm{CV} \\
\left(\Omega, \Omega_{\mathrm{TIME}}\right)\end{array}$ & 76.00 & -8.05 & 2400 & $\begin{array}{l}60 \\
(1452-1997)\end{array}$ & $\begin{array}{l}62 \\
(1816-1997)\end{array}$ & $\begin{array}{l}68 \pm 2 \\
(1965-1997)\end{array}$ & $\begin{array}{l}70 \\
(1992-1997)\end{array}$ & Karlöf et al. (2000) \\
\hline $\begin{array}{l}\text { B31 } \\
\text { (locality DML07) } \\
\left(\Omega, \Omega_{\text {TIME }}\right)\end{array}$ & 75.58 & -3.43 & 2669 & $\begin{array}{l}63 \\
(1259-1997)\end{array}$ & $\begin{array}{l}58.4 \\
(1816-1997)\end{array}$ & $\begin{array}{l}59.8 \\
(1960-1996)\end{array}$ & & $\begin{array}{l}\text { Sommer et al. (2000); } \\
\text { Oerter et al. (2000) }\end{array}$ \\
\hline $\begin{array}{l}\text { NUS08-2 } \\
(\Omega)\end{array}$ & 87.85 & -1.80 & 2583 & $\begin{array}{l}67.4 \pm 2.6 \\
(1815-2007 / 8)\end{array}$ & $\begin{array}{l}67.4 \pm 2.6 \\
(1815-2007 / 8)\end{array}$ & $\begin{array}{l}63.4 \pm 4.2 \\
(1963-2007 / 8)\end{array}$ & & Anschutz et al. (2011) \\
\hline $\begin{array}{l}\text { SOUTH POLE } \\
\left(\Omega, \Omega_{\text {TIME }}\right)\end{array}$ & 90.00 & 0.00 & 2850 & $\begin{array}{l}78.0 \pm 2.2 \\
(1801-1991)\end{array}$ & $\begin{array}{l}76.5 \\
(1816-1956)\end{array}$ & $\begin{array}{l}84.8 \pm 3.3 \\
(1965-1994)\end{array}$ & $\begin{array}{l}84.5 \pm 8.9 \\
(1992-1997)\end{array}$ & $\begin{array}{l}\text { Mosley-Thompson (1999); } \\
\text { van der Veen et al. (1999a); } \\
\text { Kaspari et al. (2004) }\end{array}$ \\
\hline $\begin{array}{l}\text { B32 } \\
\text { (locality DML05) } \\
\left(\Omega, \Omega_{\text {TIME }}\right)\end{array}$ & 75.00 & 0.01 & 2882 & $\begin{array}{l}60.9 \\
(1259-1997)\end{array}$ & $\begin{array}{l}63 \\
(1816-1997)\end{array}$ & $\begin{array}{l}80 \\
(1966-1997)\end{array}$ & & $\begin{array}{l}\text { Sommer et al. (2000); } \\
\text { Oerter et al. (2000) }\end{array}$ \\
\hline $\begin{array}{l}\text { AMUNDSENISEN } \\
(\Omega)\end{array}$ & 75.00 & 2.00 & 2900 & $\begin{array}{l}77 \\
(1865-1991)\end{array}$ & $\begin{array}{l}78 \\
(1865-1965)\end{array}$ & $\begin{array}{l}76 \\
(1966-1991)\end{array}$ & & Isaksson et al. (1996) \\
\hline $\begin{array}{l}\mathrm{S} 100 \\
\left(\Omega, \Omega_{\mathrm{TIME}}\right)\end{array}$ & 70.23 & 4.80 & 48 & $\begin{array}{l}290 \pm 90 \\
(1737-2000)\end{array}$ & $\begin{array}{l}292 \\
(1816-2000)\end{array}$ & $\begin{array}{l}284 \\
(1956-2000)\end{array}$ & $\begin{array}{l}260 \pm 80 \\
(1991-2000)\end{array}$ & Kaczmarska et al. (2004) \\
\hline $\begin{array}{l}\text { B33 } \\
\text { (locality DML17) } \\
\left(\Omega, \Omega_{\text {TIME }}\right)\end{array}$ & 75.16 & 6.50 & 3160 & $\begin{array}{l}44.4 \\
(1259-1997)\end{array}$ & $\begin{array}{l}45.9 \\
(1816-1997)\end{array}$ & $\begin{array}{l}55 \\
(1966-1989)\end{array}$ & & $\begin{array}{l}\text { Sommer et al. (2000); } \\
\text { Oerter et al. (2000) }\end{array}$ \\
\hline $\begin{array}{l}\text { NUS07-1 } \\
(\Omega)\end{array}$ & 74.72 & 7.98 & 3174 & $\begin{array}{l}52 \pm 2 \\
(1815-2007 / 8)\end{array}$ & $\begin{array}{l}52 \pm 2 \\
(1815-2007 / 8)\end{array}$ & $\begin{array}{l}55.9 \pm 3.9 \\
(1963-2007 / 08)\end{array}$ & & $\begin{array}{l}\text { Anschutz et al. (2009, } \\
\text { 2011) }\end{array}$ \\
\hline $\begin{array}{l}\text { SITE I } \\
(\Omega)\end{array}$ & 73.72 & 7.98 & 3174 & & $\begin{array}{l}52.0 \pm 1.3 \\
(1816-2007)\end{array}$ & $\begin{array}{l}56.0 \pm 4.7 \\
(1963-2007)\end{array}$ & & Anschutz et al. (2009) \\
\hline $\begin{array}{l}\text { NUS08-6 } \\
(\Omega)\end{array}$ & 81.70 & 8.57 & 2447 & $\begin{array}{l}39.2 \pm 1.5 \\
(1815-2007 / 8)\end{array}$ & $\begin{array}{l}39.2 \pm 1.5 \\
(1815-2007 / 8)\end{array}$ & $\begin{array}{l}49.2 \pm 3.4 \\
(1963-2007 / 8)\end{array}$ & & Anschutz et al. (2011) \\
\hline $\begin{array}{l}\text { M150 } \\
(\Omega)\end{array}$ & 74.99 & 15.00 & 3470 & 43 & $\begin{array}{l}43 \\
(1816)\end{array}$ & $\begin{array}{l}45 \pm 4 \\
(1965-1996)\end{array}$ & & Isaksoon et al. (1999) \\
\hline $\begin{array}{l}\text { M, MA, MB, MC, } \\
\mathrm{MD} \\
(\Omega)\end{array}$ & 75.00 & 15.00 & 3470 & & $\begin{array}{l}41.0 \pm 0.7 \\
(1816-1884)\end{array}$ & $\begin{array}{l}41.0 \pm 0.5 \\
(1955-2000)\end{array}$ & & Karlöf et al. (2005) \\
\hline $\begin{array}{l}\text { NUS08-5 } \\
(\Omega)\end{array}$ & 82.63 & 17.87 & 2544 & $\begin{array}{l}35.5 \pm 0.8 \\
(1259-2007 / 8)\end{array}$ & $\begin{array}{l}35.0 \pm 0.8 \\
(1815-2007 / 8)\end{array}$ & $\begin{array}{l}37.6 \pm 2.3 \\
(1963-2007 / 8)\end{array}$ & & Anschutz et al. (2011) \\
\hline $\begin{array}{l}\text { NUS08-4 } \\
(\Omega)\end{array}$ & 82.82 & 18.90 & 2552 & $\begin{array}{l}37.2 \pm 1.3 \\
(1622-2007 / 8)\end{array}$ & $\begin{array}{l}36.7 \pm 0.9 \\
(1815-2007 / 8)\end{array}$ & $\begin{array}{l}36.1 \pm 2.1 \\
(1963-2007 / 8)\end{array}$ & & Anschutz et al. (2011) \\
\hline
\end{tabular}


Table 1. Continued.

\begin{tabular}{|c|c|c|c|c|c|c|c|c|c|}
\hline Site name & & $\begin{array}{l}\text { Latitude } \\
\left({ }^{\circ}\right)\end{array}$ & $\begin{array}{l}\text { Longitude } \\
\left({ }^{\circ}\right)\end{array}$ & $\begin{array}{l}\text { Elevation } \\
(\mathrm{m})\end{array}$ & $\begin{array}{l}\text { Entire Record } \\
\left(\mathrm{kg} \mathrm{m}^{-2} \mathrm{yr}^{-1}\right)\end{array}$ & $\begin{array}{l}\text { Tambora- present } \\
\left(\mathrm{kg} \mathrm{m}^{-2} \mathrm{yr}^{-1}\right)\end{array}$ & $\begin{array}{l}\text { 1960s- } \\
\text { present } \\
\left(\mathrm{kg} \mathrm{m}^{-2} \mathrm{yr}^{-1}\right)\end{array}$ & $\begin{array}{l}\text { Present } \\
\left(\mathrm{kg} \mathrm{m}^{-2} \mathrm{yr}^{-1}\right)\end{array}$ & References \\
\hline $\begin{array}{l}\text { NUS08-3 } \\
(\Omega)\end{array}$ & & 84.13 & 22.00 & 2625 & $\begin{array}{l}38.8 \pm 1.4 \\
(1641-2007 / 8)\end{array}$ & $\begin{array}{l}40.1 \pm 1 \\
(1815-2007 / 8)\end{array}$ & $\begin{array}{l}45.3 \pm 3.1 \\
(1963-2007 / 8)\end{array}$ & & Anschutz et al. (2011) \\
\hline $\begin{array}{l}\text { NUS07-2 } \\
(\Omega)\end{array}$ & & 76.07 & 22.47 & 3582 & $\begin{array}{l}33.3 \pm 1.2 \\
(1259-2007 / 8)\end{array}$ & $\begin{array}{l}33.0 \pm 0.7 \\
(1815-2007 / 8)\end{array}$ & $\begin{array}{l}28 \pm 2 \\
(1963-2007 / 8)\end{array}$ & & Anschutz et al. (2011) \\
\hline MP & & 75.89 & 25.83 & 3661 & & $\begin{array}{l}33.1 \pm 1.0 \\
(1286-2008)\end{array}$ & $\begin{array}{l}38.7 \pm 0.9 \\
(1964-2008)\end{array}$ & & Fujita et al. (2011) \\
\hline $\begin{array}{l}\text { NUS07-3 } \\
(\Omega)\end{array}$ & & 77.00 & 26.01 & 3589 & $\begin{array}{l}27.8 \pm 1 \\
(1600-2007 / 8)\end{array}$ & $\begin{array}{l}22.0 \pm 0.5 \\
(1815-2007 / 8)\end{array}$ & $\begin{array}{l}23.7 \pm 1.7 \\
(1963-2007 / 8)\end{array}$ & & $\begin{array}{l}\text { Anschutz et al. (2009, } \\
\text { 2011) }\end{array}$ \\
\hline $\begin{array}{l}\text { NUS07-4 } \\
(\Omega)\end{array}$ & & 78.22 & 32.85 & 3595 & $\begin{array}{l}20.9 \pm 0.8 \\
(1622-2007 / 8)\end{array}$ & $\begin{array}{l}19.0 \pm 0.5 \\
(1815-2007 / 8)\end{array}$ & $\begin{array}{l}17.5 \pm 1.2 \\
(1963-2007 / 8)\end{array}$ & & $\begin{array}{l}\text { Anschutz et al. (2009, } \\
\text { 2011) }\end{array}$ \\
\hline $\begin{array}{l}\text { NUS07-5 } \\
(\Omega)\end{array}$ & & 78.65 & 35.63 & 3619 & $\begin{array}{l}26.0 \pm 0.9 \\
(1259-2007 / 8)\end{array}$ & $\begin{array}{l}24 \pm 0.5 \\
(1815-2007 / 8)\end{array}$ & $\begin{array}{l}20.1 \pm 1.4 \\
(1963-2007 / 8)\end{array}$ & & Anschutz et al. (2011) \\
\hline $\begin{array}{l}\text { DOME FUJI } \\
(\Omega)\end{array}$ & & 77.32 & 39.70 & 3810 & $\begin{array}{l}25.5 \pm 0.3 \\
(1260-2001)\end{array}$ & $\begin{array}{l}26.3 \\
(1816-2001)\end{array}$ & $\begin{array}{l}28.8 \pm 0.7 \\
(1964-2008)\end{array}$ & $\begin{array}{l}27.3 \pm 0.3 \\
(1995-2006)\end{array}$ & $\begin{array}{l}\text { Kameda et al. (2008); } \\
\text { Fujita et al. (2011); } \\
\text { Igarashi et al. (2011) }\end{array}$ \\
\hline YM85 & & 71.58 & 40.63 & 2246 & $\begin{array}{l}97 \\
(1260-2002)\end{array}$ & $\begin{array}{l}140 \\
(1816-2002)\end{array}$ & $\begin{array}{l}135 \\
(1965-2002)\end{array}$ & & Takahashi et al. (2009) \\
\hline H 72 & & 69.20 & 41.08 & 1214 & $\begin{array}{l}311 \\
(1831-1998)\end{array}$ & $\begin{array}{l}311 \\
(1831-1998)\end{array}$ & 307 & $\begin{array}{l}307 \\
(1973-1998)\end{array}$ & Nishio et al. (2002) \\
\hline $\begin{array}{l}\text { PR-B } \\
\text { (PLATEAU } \\
\text { MOTE) }\end{array}$ & RE- & 84.00 & 43.00 & 3330 & $\begin{array}{l}37.7 \\
(1816-1986)\end{array}$ & $\begin{array}{l}37.5 \\
(1816-1986)\end{array}$ & $\begin{array}{l}37 \\
(1986-1968)\end{array}$ & & Cole-Dai et al. (2000) \\
\hline $\begin{array}{l}\text { NUS07-6 } \\
(\Omega)\end{array}$ & & 80.78 & 44.85 & 3672 & $\begin{array}{l}21.1 \pm 0.7 \\
(1600-2007 / 8)\end{array}$ & $\begin{array}{l}16.0 \pm 0.4 \\
(1815-2007 / 8)\end{array}$ & & & $\begin{array}{l}\text { Anschutz et al. (2009, } \\
\text { 2011) }\end{array}$ \\
\hline G15 & & 71.20 & 45.98 & 2544 & $\begin{array}{l}130 \\
(1210-1984)\end{array}$ & $\begin{array}{l}86 \\
(1816-1964)\end{array}$ & $\begin{array}{l}116 \\
(1964-1984)\end{array}$ & & Moore et al. (1991) \\
\hline $\begin{array}{l}\text { NUS07-8 } \\
\left(\Omega, \Omega_{\mathrm{TIME}}\right)\end{array}$ & & 84.18 & 53.53 & 3452 & $\begin{array}{l}32.0 \pm 1.2 \\
(1815-2007 / 8)\end{array}$ & $\begin{array}{l}32.0 \pm 1.2 \\
(1815-2007 / 8)\end{array}$ & $\begin{array}{l}30 \pm 2.1 \\
(1963-2007 / 8)\end{array}$ & & $\begin{array}{l}\text { Anschutz et al. (2009, } \\
\text { 2011) }\end{array}$ \\
\hline $\begin{array}{l}\text { NUS07-8 } \\
(\Omega)\end{array}$ & & 84.18 & 53.53 & 3452 & & $\begin{array}{l}32 \pm 1.2 \\
(1816-2007)\end{array}$ & $\begin{array}{l}30 \pm 2.1 \\
(1963-2007)\end{array}$ & & Anschutz et al. (2009) \\
\hline $\begin{array}{l}\text { NUS07-7 } \\
(\Omega)\end{array}$ & & 82.07 & 54.55 & 3725 & $\begin{array}{l}29.5 \pm 1 \\
(1259-2007 / 8)\end{array}$ & $\begin{array}{l}29.4 \pm 0.6 \\
(1815-2007 / 8)\end{array}$ & $\begin{array}{l}26.1 \pm 1.9 \\
(1963-2007 / 8)\end{array}$ & & Anschutz et al. (2011) \\
\hline DT401 & & 79.02 & 77.00 & 3760 & $\begin{array}{l}29 \\
(1999-186)\end{array}$ & $\begin{array}{l}19 \\
(1999-1816)\end{array}$ & $\begin{array}{l}24 \\
(1999-1963)\end{array}$ & $\begin{array}{l}25 \pm 16 \\
(1999-2005)\end{array}$ & $\begin{array}{l}\text { Ren et al. (2010); } \\
\text { Ding et al. (2011a) }\end{array}$ \\
\hline $\begin{array}{l}\text { DT001 } \\
(\Omega)\end{array}$ & & 70.83 & 77.07 & 2325 & $\begin{array}{l}127 \\
(1745-1996)\end{array}$ & $\begin{array}{l}131 \\
(1810-1959)\end{array}$ & $\begin{array}{l}131 \\
(1959-1996)\end{array}$ & & Zhang et al. (2006) \\
\hline $\begin{array}{l}\text { Dome A } \\
(\Omega)\end{array}$ & & 80.36 & 77.36 & 4092 & $\begin{array}{l}23 \\
(1260-1998)\end{array}$ & $\begin{array}{l}23 \\
(1815-1998)\end{array}$ & $\begin{array}{l}23 \\
(1963-1998)\end{array}$ & & $\begin{array}{l}\text { Hou et al. (2007); } \\
\text { Jiang et al. (2012) }\end{array}$ \\
\hline LGB65 & & 71.85 & 77.92 & 1850 & 127 & 131 & 131 & & Xiao et al. (2004) \\
\hline $\begin{array}{l}\text { VOSTOK } \\
(\Omega)\end{array}$ & & 78.45 & 106.83 & 3488 & & $\begin{array}{l}20.6 \pm 0.3 \\
(1816-\text { present })\end{array}$ & $\begin{array}{l}21.5 \pm 0.5 \\
(1955 \text {-present })\end{array}$ & $\begin{array}{l}20.8 \\
(1958-2010)\end{array}$ & $\begin{array}{l}\text { Ekaykin et al. (2004) } \\
\text { http://south.aari.nw.ru/ } \\
\text { stations/vostok/vostok_en. } \\
\text { html }\end{array}$ \\
\hline $\begin{array}{l}\text { LAW DOME } \\
\left(\Omega, \Omega_{\text {TIME }}\right)\end{array}$ & & 66.77 & 112.98 & 1370 & 680 & $\begin{array}{l}687 \\
(1966-1816)\end{array}$ & $\begin{array}{l}742 \\
(1966-2005)\end{array}$ & & $\begin{array}{l}\text { Morgan et al. (1991); } \\
\text { Van Ommen (2010) }\end{array}$ \\
\hline $\begin{array}{l}\text { DOME C } \\
(\Omega)\end{array}$ & & 75.12 & 123.31 & 3233 & $\begin{array}{l}<25 \\
(1259-1998)\end{array}$ & $\begin{array}{l}25.3 \\
(1816-1998)\end{array}$ & $\begin{array}{l}28.3 \\
(1965-1998)\end{array}$ & $\begin{array}{l}28 \\
(2004-2011)\end{array}$ & $\begin{array}{l}\text { Urbini et al. (2008); Frez- } \\
\text { zotti et al. (2005); Castel- } \\
\text { lano et al. (2005); http: } \\
\text { //www-lgge.ujf-grenoble. } \\
\text { fr/ServiceObs/ } \\
\text { SiteWebAntarc/dc.php }\end{array}$ \\
\hline $\begin{array}{l}\text { D6 A } \\
\left(\Omega, \Omega_{\mathrm{TIME}}\right)\end{array}$ & & 75.44 & 129.81 & 3027 & & $\begin{array}{l}36.0 \pm 1.8 \\
(1816-1998)\end{array}$ & $\begin{array}{l}29.0 \pm 1.4 \\
(1966-1998)\end{array}$ & $\begin{array}{l}39 \\
(1998-2002)\end{array}$ & Frezzotti et al. (2005) \\
\hline D66 & & 68.94 & 136.94 & 2333 & & $\begin{array}{l}196 \\
(1966-1864)\end{array}$ & $\begin{array}{l}213 \pm 13 \\
(1965-2001)\end{array}$ & $\begin{array}{l}197 \\
(2001-2003)\end{array}$ & $\begin{array}{l}\text { Magand et al. (2004); } \\
\text { This paper }\end{array}$ \\
\hline $\begin{array}{l}\text { D2 A } \\
(\Omega)\end{array}$ & & 75.62 & 140.63 & 2479 & & $\begin{array}{l}20.0 \pm 1.0 \\
(1816-1998)\end{array}$ & $\begin{array}{l}31.0 \pm 1.6 \\
(1966-1998)\end{array}$ & $\begin{array}{l}30 \\
(1998-2002)\end{array}$ & Frezzotti et al. (2005) \\
\hline $\begin{array}{l}\text { GV1 } \\
(\Omega)\end{array}$ & & 70.87 & 141.38 & 2244 & & $\begin{array}{l}114 \\
(1816-2001)\end{array}$ & $\begin{array}{l}117 \pm 7 \\
(1965-2001)\end{array}$ & $\begin{array}{l}96 \\
(2001-2003)\end{array}$ & $\begin{array}{l}\text { Magand et al. (2004); } \\
\text { this paper }\end{array}$ \\
\hline $\begin{array}{l}\text { GV2 } \\
(\Omega)\end{array}$ & & 71.71 & 145.26 & 2143 & & $\begin{array}{l}112 \\
(1816-2001)\end{array}$ & $\begin{array}{l}112 \pm 7 \\
(1965-2001)\end{array}$ & $\begin{array}{l}92 \\
(2001-2003)\end{array}$ & $\begin{array}{l}\text { Magand et al. (2004); } \\
\text { this paper }\end{array}$ \\
\hline $\begin{array}{l}\text { MDPT A } \\
(\Omega)\end{array}$ & & 75.53 & 145.86 & 2454 & & $\begin{array}{l}36.0 \pm 1.8 \\
(1816-1998)\end{array}$ & $\begin{array}{l}45.0 \pm 2.7 \\
(1966-1998)\end{array}$ & $\begin{array}{l}47 \\
(1998-2010)\end{array}$ & $\begin{array}{l}\text { Frezzotti et al. (2005); } \\
\text { this paper }\end{array}$ \\
\hline $\begin{array}{l}\text { GV3 } \\
(\Omega)\end{array}$ & & 72.63 & 150.17 & 2137 & & $\begin{array}{l}81 \\
(1816-2001)\end{array}$ & $\begin{array}{l}84 \pm 5 \\
(1965-2001)\end{array}$ & $\begin{array}{l}73 \\
(2001-2003)\end{array}$ & $\begin{array}{l}\text { Magand et al. (2004); } \\
\text { this paper }\end{array}$ \\
\hline M2 A & & 74.80 & 151.27 & 2278 & & $\begin{array}{l}17.0 \pm 0.8 \\
(1816-1998)\end{array}$ & $\begin{array}{l}15.0 \pm 7.5 \\
(1966-1998)\end{array}$ & $\begin{array}{l}8.5 \\
(1998-2002)\end{array}$ & Frezzotti et al. (2005) \\
\hline
\end{tabular}


Table 1. Continued.

\begin{tabular}{|c|c|c|c|c|c|c|c|c|}
\hline Site name & $\begin{array}{l}\text { Latitude } \\
\left({ }^{\circ}\right)\end{array}$ & $\begin{array}{l}\text { Longitude } \\
\left({ }^{\circ}\right)\end{array}$ & $\begin{array}{l}\text { Elevation } \\
(\mathrm{m})\end{array}$ & $\begin{array}{l}\text { Entire Record } \\
\left(\mathrm{kg} \mathrm{m}^{-2} \mathrm{yr}^{-1}\right)\end{array}$ & $\begin{array}{l}\text { Tambora- present } \\
\left(\mathrm{kg} \mathrm{m}^{-2} \mathrm{yr}^{-1}\right)\end{array}$ & $\begin{array}{l}\text { 1960s- } \\
\text { present } \\
\left(\mathrm{kg} \mathrm{m}^{-2} \mathrm{yr}^{-1}\right)\end{array}$ & $\begin{array}{l}\text { Present } \\
\left(\mathrm{kg} \mathrm{m}^{-2} \mathrm{yr}^{-1}\right)\end{array}$ & References \\
\hline $\begin{array}{l}\text { GV4 } \\
(\Omega)\end{array}$ & 72.39 & 154.48 & 2126 & & $\begin{array}{l}119 \\
(1816-2001)\end{array}$ & $\begin{array}{l}100 \pm 6 \\
(1965-2001)\end{array}$ & $\begin{array}{l}96 \\
(2001-2003)\end{array}$ & $\begin{array}{l}\text { Magand et al. (2004); } \\
\text { this paper }\end{array}$ \\
\hline $\begin{array}{l}31 \mathrm{DPT} \text { A } \\
\left(\Omega, \Omega_{\mathrm{TIME}}\right)\end{array}$ & 74.03 & 155.96 & 2069 & & $\begin{array}{l}98.0 \pm 4.9 \\
(1816-1998)\end{array}$ & $\begin{array}{l}112.0 \pm 5.6 \\
(1966-1998)\end{array}$ & $\begin{array}{l}98 \\
(1998-2002)\end{array}$ & Frezzotti et al. (2005) \\
\hline GPS2A & 74.64 & 157.502 & 1804 & $\begin{array}{l}102 \\
(1745-1998)\end{array}$ & $\begin{array}{l}60.0 \pm 3.0 \\
(1816-1998)\end{array}$ & $\begin{array}{l}54.0 \pm 2.7 \\
(1966-1998)\end{array}$ & $\begin{array}{l}55 \\
(1993-2000)\end{array}$ & Frezzotti et al. (2005) \\
\hline $\begin{array}{l}\text { GV5 } \\
\left(\Omega, \Omega_{\text {TIME }}\right)\end{array}$ & 71.89 & 158.54 & 2184 & & $\begin{array}{l}129 \\
(1816-2001)\end{array}$ & $\begin{array}{l}129 \pm 7 \\
(1965-2001)\end{array}$ & $\begin{array}{l}135 \\
(2001-2004)\end{array}$ & $\begin{array}{l}\text { Magand et al. (2004); } \\
\text { Frezzotti et al. (2007) }\end{array}$ \\
\hline $\begin{array}{l}\text { GV7 } \\
\left(\Omega, \Omega_{\mathrm{TIME}}\right)\end{array}$ & 70.68 & 158.86 & 1947 & & $\begin{array}{l}237 \\
(1854-2001)\end{array}$ & $\begin{array}{l}241 \pm 13 \\
(1965-2001)\end{array}$ & $\begin{array}{l}252 \\
(2001-2004)\end{array}$ & $\begin{array}{l}\text { Magand et al. (2004); } \\
\text { Frezzotti et al. (2007) }\end{array}$ \\
\hline $\begin{array}{l}\text { TALOS DOME } \\
\left(\Omega, \Omega_{\text {TIME }}\right)\end{array}$ & 72.77 & 159.08 & 2316 & $\begin{array}{l}80 \\
(1259-1996)\end{array}$ & $\begin{array}{l}83.6 \\
(1816-2001)\end{array}$ & $\begin{array}{l}86.6 \\
(1966-1996)\end{array}$ & $\begin{array}{l}68 \\
(2001-2010)\end{array}$ & $\begin{array}{l}\text { Magand et al. (2004); } \\
\text { Frezzotti et al. (2007); } \\
\text { this paper }\end{array}$ \\
\hline $\begin{array}{l}\text { HERCULES } \\
\text { NEVE } \\
(\Omega, \Omega \text { TIME })\end{array}$ & 73.10 & 165.40 & 2960 & $\begin{array}{l}119 \\
(1770-1992)\end{array}$ & $\begin{array}{l}118 \\
(1816-1966)\end{array}$ & $\begin{array}{l}129 \\
(1966-1992)\end{array}$ & & Stenni et al. (1999) \\
\hline
\end{tabular}

a i.e., ice equivalent; $\Omega$ site member of the verified dataset (see text for details); $\Omega$ TIME site member of the verified dataset for which an annually time-resolved SMB time series exists.

when the seasonal stratigraphy is unavailable or uncertain. When available, stake farm measurements are used to complete the most recent record (from the 1990s to the present) of previous firn/ice core measurements.

The snow redistribution process and relative surface roughness (e.g., sastrugi formations) have a strong impact on the annual variability of the SMB at the annual/metre scale (i.e., noise in ice cores). The accumulation/ablation pattern emerging from the stake farm measurements makes it possible to survey the accumulation values and noise on an annual scale by comparing the variations in the accumulation at each stake with the average across the stake farm. The detected "noise", represented by the standard deviation of the measured values, largely reflects the snow surface roughness (sastrugi) and limits the degree to which a single annual SMB value may be considered representative (Frezzotti et al., 2007; Kameda et al., 2008; Ding et al., 2011a).

The stake farm measurements demonstrate that accumulation hiatuses and/or erosion can occur at sites with accumulation rates below $120 \mathrm{~kg} \mathrm{~m}^{-2} \mathrm{yr}^{-1}$ (Frezzotti et al., 2005, 2007; Ding et al., 2011a). The differences between the cores and stakes can lead to the statistical misidentification of annual layers determined from seasonal signals at sites with SMB rates below $200 \mathrm{~kg} \mathrm{~m}^{-2} \mathrm{yr}^{-1}$ due to the inability to detect higher and lower values. With an average roughness height of $20-40 \mathrm{~cm}$, achieving $\pm 10 \%$ accuracy in the reconstruction of the SMB from single cores requires high accumulations ( $\left.>700 \mathrm{~kg} \mathrm{~m}^{-2} \mathrm{yr}^{-1}\right)$. Low-accumulation sites are representative if their cumulative rates are computed over several years. Variations in the multi-year averages of the annual SMB decrease with the square root of the number of observation years (McConnell et al., 1997; van der Veen et al., 1999b; Goodwin et al., 2003; Frezzotti et al., 2007; Kameda et al., 2008; Banta et al., 2008). SMB records have been computed using cumulative rates over several years to reach an approximate $700 \mathrm{~kg} \mathrm{~m}^{-2} \mathrm{yr}^{-1}$ threshold, allowing the estimation of the annual SMB at $\pm 10 \%$ accuracy, which is comparable to the accuracy obtained with instrumental measurements (e.g., those measuring rain precipitation).

The snow radar survey shows that the spatial variability of the SMB at the kilometre scale is one order of magnitude higher than the temporal variability at the multidecadal/centennial scale. Depending on the study area, the distributions can be homogeneous over hundreds of kilometres on the polar plateau, particularly at ice divides and domes, or they can vary considerably at locations with high spatial accumulation variability due to strong wind erosion (e.g., Eisen et al., 2008; Frezzotti et al., 2005, 2007; Anschütz et al., 2008, 2011; Fujita et al., 2011). Therefore, the reconstruction of past climates based on firn/ice cores drilled in areas with spatial variability in SMB is a complicated process (Eisen et al., 2008). Several authors have noted the importance of conducting ancillary spatial SMB measurements as part of ice-coring programs to allow topographic effects to be deconvolved from potential climate signals (e.g., Hamilton, 2004; Frezzotti et al., 2005, 2007; Anschütz et al., 2008; Spike et al., 2004; Kaspari et al., 2004). To avoid such misleading results it is important that SMB records of insufficient or unassessed reliability (high variability or unknown SMB upstream of the core site) be discarded, even at the cost of a strong reduction in spatial and temporal coverage (Magand et al., 2007). To disregard artificial results, most of the analyses presented in this paper are applied to both the entire dataset (67 ice cores) and a restricted ensemble of 52 ice cores, hereinafter called the verified dataset $(\Omega)$, which is unaffected by upstream topographic/wind erosion effects (Fig. 1 and Table 1).

The entire dataset (67 ice cores) and the restricted group of 52 ice cores $(\Omega)$ were used to compare the present SMB (approximately the last $40 \mathrm{yr}$ ) with the SMB of previous 


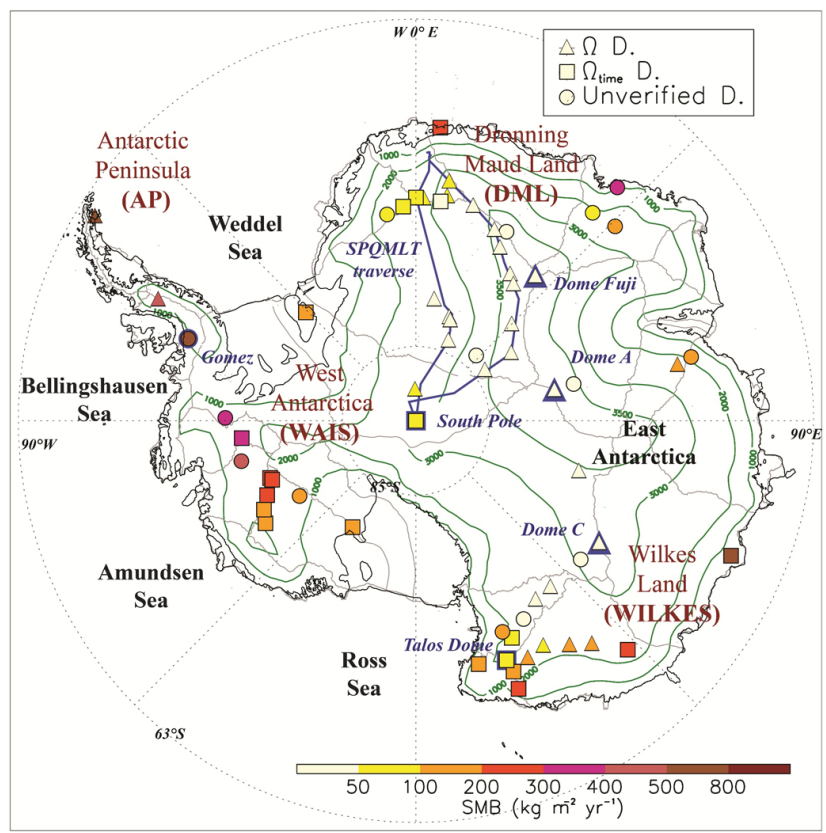

Fig. 1. Geographical distribution of firn/ice core records used in this study along with Surface Mass Balance (SMB) values $\left(\mathrm{kg} \mathrm{m}^{-2}\right.$ $\mathrm{yr}^{-1}$ ) and their reliability of the annually resolved time series used for stacked records; triangle: verified data $(\Omega)$ without a temporal series at the annual scale; square: verified data $\left(\Omega_{\text {TIME }}\right)$ with a temporal series at annual scale; circle: unverified data with unknown SMB conditions upstream of the core site or sites affected by high SMB spatial variability. Blue lines and symbols highlight the SPQMLT route, Dome Fuji, Dome A, Gomez, South Pole, Talos Dome, and Dome $\mathrm{C}$ sites respectively. Ice divide positions and altitude isolines are shown in grey and green, respectively.

centuries. These datasets were analysed by comparing the average values from the 2000s to the 1960s $(\beta 40)$ with two previous time windows: from the 1960s to $1815(\beta 150)$ and from the 1960s through approximately the last $800 \mathrm{yr}(\beta$ tot). The variations between the last two periods were also studied.

To understand the temporal variability of the SMB at the decadal scale, we used the annually resolved SMB records to create different stacked records that are representative of the continental and regional scales. The dataset used $\left(\Omega_{\mathrm{TIME}}\right)$ is a subsample of the $\Omega$ dataset; it contains 21 cores in which it is possible to obtain an annually resolved time series record because the accumulation mean value at the site is higher than approximately $70 \mathrm{~kg} \mathrm{~m}^{-2} \mathrm{yr}^{-1}$. To homogenise the dataset and disregard noise caused by post depositional effects, the SMB records were smoothed using 15-yr backward averaging. The 15-yr smoothing window was chosen because it is the minimum number of years necessary for the core with the smallest accumulation (Talos Dome, B31, B32, B33) to reach the threshold accumulation value of approximately $700 \mathrm{~kg} \mathrm{~m}^{-2} \mathrm{yr}^{-1}$, ensuring that the accumulation variability will be within $\pm 10 \%$ of its mean value. In the second step, the cores were normalised (the anomaly from the mean divided by the standard deviation) to allow comparisons between sites with very different accumulation values. Finally, the mean continental values were determined by averaging all of the available data for each single year from 1200 to 2010 . Using the same methodology, three regional patterns were also created by averaging the WAIS (Siple Dome, ITASE00_5, ITASE00_4, RIDSA, DC05A, DC05Q, ITASE00_1, and ITASE01_3), DML (South Pole, Berkner B25, B31, B32, B33, and S100) and WILKES (Hercules Nèvè, 31Dpt, Talos Dome, GV5, GV7, D66, and Law Dome) site records.

The spatial and temporal representativeness of ice core average can be a very difficult task. The methodology used is very simple, but considering the available dataset and the temporal scale analysed in this study, it is not possible to apply a more complex methodology.

A continental stacked record obtained by averaging the regional stacked series instead of averaging the entire record was tested to minimise the possible presence of biases due to an excessively high record density in particular areas (data not shown). However, the identified differences are very small $(<1 \%)$ and are not statistically significant. A KruskalWallis H-Test ensures that the 21 cores of $\Omega_{\mathrm{TIME}}$ have the same mean of distribution and that differs within a confidence level of 95 . Moreover, the longest ice core time series results are within one standard deviation for $87 \%$ (19801918) of the entire continent time series, $85 \%$ (1980-1918) of the WAIS, $75 \%$ (1980-1766) of the DML, and $78 \%$ (1990-1882) of the WILKES. These time windows represent the periods with the maximum number of available ice cores for each average record.

Monaghan et al. (2006) developed an innovative technique for the study of snowfall over the last 5 decades (1955-2005). The novel methodology utilises a predictor function based on the simulated precipitation from the European Centre for Medium Range Weather Forecast - European Re-Analysis 40 (ECMWF ERA-40) snowfall field, from 1960 to 2000, and is used to interpolate various instrumental measurements (e.g., ice core and snow pit data and daily observations). Monaghan et al. (2006) chose 1985-1994 as the reference decade, which allows the ERA-40 precipitation to be both calibrated against the instrumental record and adjusted for biases. Unfortunately, this technique is unusable in this study because the Reanalysis ERA-40 dataset ends at 1958. For this reason, it is not possible to calculate the predictor function prior to that year. Furthermore, it is not possible to interpolate $\Omega_{\text {TIME }}$ data using the model predictor based on one of the last five decades because this analysis method would imply that the atmospheric dynamics have not changed over the last $800 \mathrm{yr}$, which is a highly questionable assumption. The distribution of the SMB dataset is not completely balanced, with inadequate SMB records in coastal and slope areas with high accumulation, particularly in the WAIS and in the Indian Sector of the EAIS between $30^{\circ} \mathrm{E}$ and $110^{\circ} \mathrm{E}$ (Fig. 1). However, 


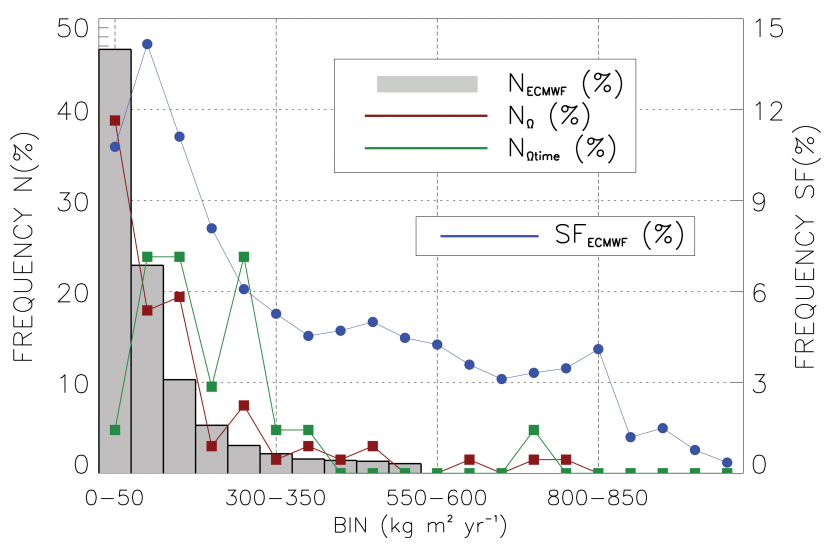

Fig. 2. Relative frequency (left side axis) of the ECMWF ERA INTERIM snowfall field over the Antarctica $\left(N_{\mathrm{ECMWF}}\right.$, grey-filled vertical bars) and SMB measurements for the $\Omega\left(N_{\Omega}\right)$ and $\Omega_{\text {time }}$ $\left(N_{\Omega \text { time }}\right)$ datasets (red and green lines, respectively) occurring in bins $50 \mathrm{~kg} \mathrm{~m}^{-2} \mathrm{yr}^{-1}$ wide. The blue line represents the contribution (relative frequency, right side axis) of each bin to total snowfall over Antarctica calculated from ECMWF ERA INTERIM snowfall field $\left(\mathrm{SF}_{\mathrm{ECMWF}}\right)$.

a comparison between the ECMWF ERA INTERIM snowfall and the SMB distribution densities (Fig. 2) shows that the entire dataset ( 67 records) is representative of the entire snowfall spectrum of the model at the continental scale $(0.05$ significance level). Otherwise, the dataset $\Omega_{\mathrm{TIME}}$ ( 21 cores) is representative of only the medium/high accumulation site of Antarctica, which represents approximately $50 \%$ of the snowfall (Fig. 2) and $50 \%$ of the AIS surface (not shown).

The snowfall frequency spectrum, discussed above, is presumably modulated by the variability of cyclonic/anticyclonic pressure systems that characterise weather patterns over the Southern Ocean and around Antarctica. Indeed, intermittent blocking anticyclone events in the Southern Ocean cause significant precipitation events over the AIS by conveying warm and moist air masses along the coast and the slope of the continent and even into the continental interior (e.g., Scarchilli et al., 2011; Schlosser et al., 2011). Thus, we also examine the connection between blocking phenomena and snow accumulation at annual and decadal time scales, calculating the numbers of blocked days for each longitudinal sector of $5^{\circ}$ in width and correlating them with the snowfall amounts. The blocking highs were calculated from the ECMWF ERA INTERIM Re-Analysis of Geopotential height at a 500-hPa field on a regular grid of $1^{\circ} \times 1^{\circ}(\mathrm{Sim}-$ mons et al., 2006). The procedure is described by Scarchilli et al. (2011). To ensure that features formed at higher latitudes than normal are included in the analysis, snowfall time series were created from the $+24 \mathrm{~h}$ forecast of the ERA INTERIM snowfall field on a regular grid of $1^{\circ} \times 1^{\circ}$. Both the blocking index and snowfall fields represent the annual cumulative values from daily values over the period 1980 2011.

\section{Results}

Figure 3a presents the geographical distribution of the differences between $\beta 40$ and $\beta 150$ (a similar pattern is also visible between $\beta 40$ and $\beta$ tot, not shown). No clear increasing/decreasing features were observed on the Antarctic continent; however, the figure highlights variations reaching approximately $\pm 50 \%$ of the SMB in nearby areas. A general increase is visible on boundaries of the WILKES area, particularly in higher plateau sites in the direction of DC, in accordance with the increase from 1960 to 1970 and during the 1990s reported by other authors (Morgan et al., 1991; Goodwin et al., 2003; Stenni et al., 2002; Frezzotti et al., 2005). In contrast, a slight decrease is apparent in the sites inland to Victoria Land, such as Talos Dome (Fig. 1). Additionally, in the WAIS region, Fig. 3a depicts an SMB increase in the Bellingshausen Sea area and a decrease in the Amundsen Sea area, which is in accordance with the SMB variations since the 1970s observed by Kaspari et al. (2004). On the other hand, only a positive increase in the SMB is present in the AP. In particular, the Gomez site $\left(73.59^{\circ} \mathrm{S}, 70.36^{\circ} \mathrm{W}\right)$ exhibited the second-greatest increase in the entire dataset. This result is in agreement with the findings of Thomas et al. (2008), who presented evidence for a unique SMB doubling since 1850 with acceleration in recent decades at this site, compared with a much smaller rate of increase in the SMB observed since the 1930s at other AP high sites (Aristrarain et al., 2004; Raymond et al., 1996).

Over the Norway-US traverse South Pole Queen Maud Land traverse (SPQMLT), and south of the ice divide of East Antarctica (IDEA), the differences between $\beta 40$ and $\beta 150$ do not present a clear overall trend. In the westerly part and at lower elevations $(<3450 \mathrm{~m})$ along the traverse, a slight increase in the SMB during $\beta 40$ is in accordance with other data on the European Project for Ice Coring in Antarctica in Dronning Maud Land (EDML ice core, Mosley-Thompson et al., 1999; Oerter et al., 2000; Hofstede et al., 2004). On the leeward sides of the ice divide with respect to the moisture source, there is a decrease or no significant change in the SMB from the southern part of the ice divide Dome FujiEDML, as described by Anschütz et al. $(2009,2011)$ and Fujita et al. (2011). The most significant changes appear to have occurred in the most recent decades at the highest site and along the ice divide, with SMB increases of approximately 10-30\% (Fig. 3a). Fujita et al. (2011) noted that the accumulation rate in the second half of the 20th century was approximately $15 \%$ higher than the average rate taken over the longer periods of $722 \mathrm{yr}$ Before Present (BP) and $7900 \mathrm{yr}$ $\mathrm{BP}$ along the highest part $(>3450 \mathrm{~m}$ ) of the IDEA from the Dome Fuji and EDML cores.

The Dome C area (Frezzotti et al., 2005; Urbini et al., 2008) has exhibited similarly high accumulations since the 1960s, as observed at the highest part of the IDEA (Fig. 3a), whereas no significant changes have been apparent at Dome A (Fig. 1) since 1260 (Ding et al., 2011a; Hou et al., 2009; 

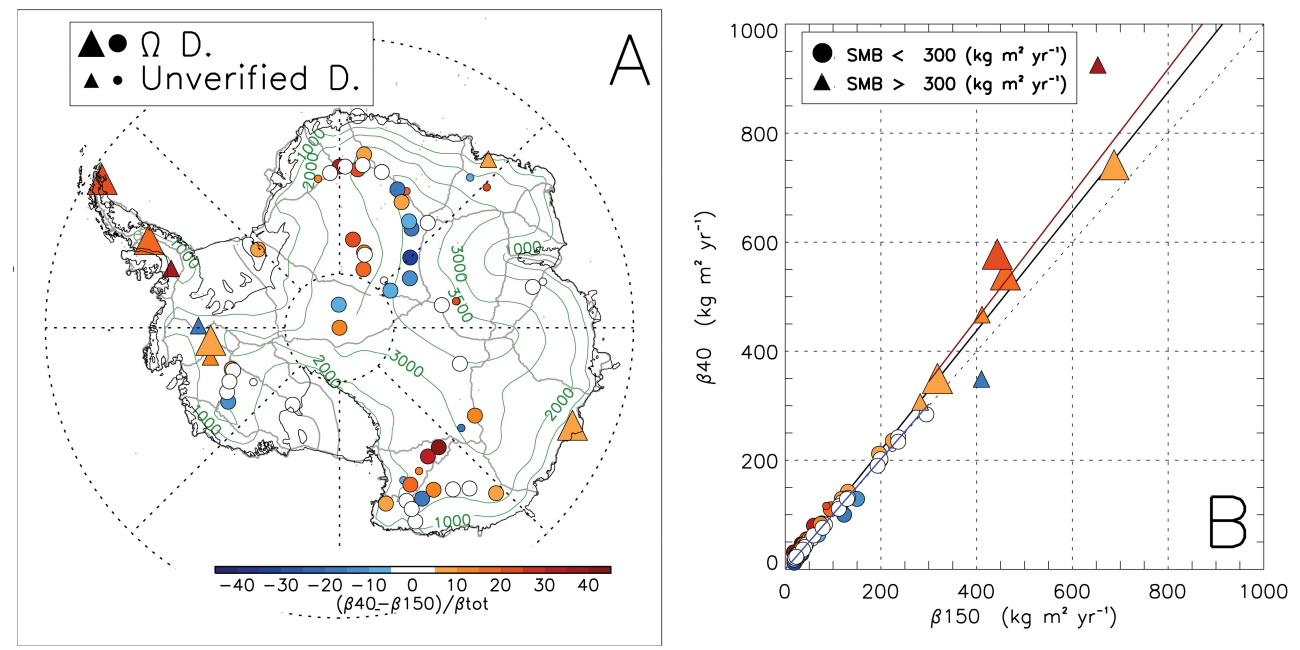

Fig. 3. (A) Geographical distribution of SMB temporal variability. Data were obtained from the ratios (expressed as percentages) of differences in the SMB values between 1960-present $(\beta 40)$ and Tambora-1960s $(\beta 150)$ with respect to the SMB values of the entire ice core length ( $\beta$ tot); sites with SMBs greater than $300 \mathrm{~kg} \mathrm{~m}^{-2} \mathrm{yr}^{-1}$ and lower than $300 \mathrm{~kg} \mathrm{~m}^{-2} \mathrm{yr}^{-1}$ are represented with triangles and filled circles, respectively. Larger symbols indicate sites included in the verified $(\Omega)$ dataset. (B) Relationships in SMB temporal variability of the last two century. Data were obtained from the values for all sites in the datasets between the 1960s-present $(\beta 40)$ and Tambora-1960s $(\beta 150)$; filled colour represents ratios (expressed as percentages) of differences in the SMB values between 1960-present ( $\beta 40)$ and Tambora1960s $(\beta 150)$ with respect to the SMB values of the entire ice core length ( $\beta$ tot). Sites with SMBs greater than $300 \mathrm{~kg} \mathrm{~m}^{-2} \mathrm{yr}^{-1}$ and lower than $300 \mathrm{~kg} \mathrm{~m}^{-2} \mathrm{yr}^{-1}$ are represented with triangles and filled circles, respectively. Larger symbols indicate sites included in the verified $(\Omega)$ dataset. Linear relation between $\beta 150$ and $\beta 40$ values using the entire verified $(\Omega)$ dataset, only values greater than and lower than $300 \mathrm{~kg} \mathrm{~m}^{-2} \mathrm{yr}^{-1}$ are represented in black, red and blue lines, respectively.

Jiang et al., 2012). The SMB variation map also shows a slight increase in the $\beta 40$ time window at the South Pole, in accordance with the findings of Mosley-Thompson et al. (1999), who suggested an increase in the SMB between 1965 and 1997 based on stake farm measurements. However, Hamilton (2004) described a topographic control of the regional accumulation rate variability at the South Pole.

Figure $3 \mathrm{~b}$ shows an increase in accumulation of approximately $9 \%\left(R^{2} 0.99\right.$; significance level $\left.>99 \%, n=52\right)$ during $\beta 40$ with respect to $\beta 150$ and an increase of approximately $6 \%\left(R^{2} 0.98\right.$; significance level $\left.>99 \%, n=52\right)$ with respect to $\beta$ tot (not shown), considering only the $\Omega$ dataset ( 52 records). The variability observed in the $\Omega$ dataset is representative of the variability in the entire dataset (not shown), but with higher values (13 and $10 \%$ for the differences of $\beta 40$ respect to $\beta 150$ and $\beta$ tot, respectively). The general SMB spatial overview observed in Fig. $3 \mathrm{a}$ and b emphasise that increases in the SMB occur mainly in sites with high SMB values of $>300 \mathrm{~kg} \mathrm{~m}^{-2} \mathrm{yr}^{-1}(+9 \% \beta 40 / \beta$ tot; $+15 \%$ $\beta 40 / \beta 150)$ and along the IDEA traverse, whereas sites with values of $<300 \mathrm{~kg} \mathrm{~m}^{-2} \mathrm{yr}^{-1}$ do not exhibit significant variations in the SMB $(+2 \% \beta 40 / \beta$ tot; $+1 \% \beta 40 / \beta 150)$. Increases in the absolute value trend for sites with SMB values $>300 \mathrm{~kg} \mathrm{~m}^{-2} \mathrm{yr}^{-1} \quad(+12 \% \quad \beta 40 / \beta$ tot; $+18 \% \quad \beta 40 / \beta 150$, Fig. 3a) are only observed when the entire dataset is considered.
An analysis of the continental time series created by averaging the 21 ice cores contained in the $\Omega_{\mathrm{TIME}}$ dataset reveals a coherent pattern at the centennial scale with three periods of low accumulation (1250-1300, 1420-1550, and 1660-1790), interrupted by periods of high accumulation that reached maximum levels in approximately the 1370s and 1610s (Fig. 4b). We observed values that are close to the average value during the 19th century and the first part of the 20th century, an increase in accumulation is apparent from the 1950s to the 1990s, which seems to be primarily driven by the WILKES stacked record (Fig. 4c). However, a decrease in the SMB has been measured during the last $10 \mathrm{yr}$, with values that are approximately equal to the long-period average. This decrease is, in part, due to the low SMB of the DML (Fig. 4d). The WAIS records reveal a decrease in the SMB between 1650 and 1725 (Fig. 4e); after 1725 until the beginning of the 20th century, a slight increase occurs, and a stable condition is maintained throughout most of the 20th century. Similar observations were previously noted by Banta et al. (2008). The regional patterns (WAIS, WILKES, and DML) show anti-phasing/phasing between the different regions, primarily before the 19 th century, but clear and common recurring patterns are not apparent.

The continental stacked record was correlated with the Total Solar Irradiance time series (TSI; Steinhilber et al., 2009, data available at ftp://ftp.ncdc.noaa.gov/pub/ data/paleo/climate_forcing/) to better understand the SMB 
potential forcing at the decadal and centennial time scales. The calculated accumulation record was smoothed with a 40yr central running average and resampled every five years to ensure that it is comparable to the TSI dataset. A comparison of the TSI and the continental stacked SMB records (Fig. 5a) reveals low accumulations during low solar activity, particularly during the Wolf minimum (1280-1359) and the Spörer minimum (1420-1540). A raw correlation $(R)$ between the TSI and accumulation (Fig. 5c) over the period of 1200-2005 yielded a value that is not particularly high $(+0.5$, significant at the $95 \%$ level), with a periodic recurrence every $100 \mathrm{yr}$. The accumulation appears to lead the TSI by a slight interval (approximately $10 \mathrm{yr}$ ); this result is in contrast to the model predictions (Schwartz et al., 2007), which described a lag of $0 /+20 \mathrm{yr}$ due to the thermal inertia of the climate system. However, we believe that this small lag in $R$ is not significant due to the low sampling rate and the various smoothing procedures applied. On the other hand, a running correlation over various time windows $(100,200$, and $300 \mathrm{yr})$ between the TSI and the continental stacked SMB series is shown in Fig. 5b. The plot depicts a very high, significant correlation for the middle period (1400-1650 AD), especially for the 200- and 300-yr windows, but a general decrease in correlation values in the period between 1650 and $1850 \mathrm{AD}$. The 100 -yr running window exhibits more scattered correlation values in periods where the two variables have the same oscillation, followed by a strong anti-correlated trend.

Intermittent blocking anticyclone events in the Southern Ocean have caused significant precipitation events over the AIS by conveying warm and moist air masses along the coast and slope of the continent, even into the continental interior. The formation of the blocking ridge is associated with the wave activity propagation of quasi stationary Rossby waves from the lower latitudes (Noone at al., 1999; Hirasawa et al., 2000; Goodwin et al., 2003; Massom et al., 2004; Scarchilli et al., 2011; Schlosser et al., 2011). The majority of the high blocking phenomena in the Southern Hemisphere generally occur in the latitude band of $35-55^{\circ}$ (Tibaldi et al., 1994), but they also occur at even higher latitudes $\left(60-70^{\circ}\right.$; Scarchilli et al., 2011) over the oceans. Figure 6a shows that on an annual basis, most of these events continue between $150^{\circ} \mathrm{E}$ and $90^{\circ} \mathrm{W}$, in accordance with various previous studies (Marques and Rao, 2000; Renwick, 1998; Gibson et al., 1995) that have stated that the Eastern Pacific Basin and, with a lower frequency and in different seasons, the Tasman Sea are the most important areas in which blocking anticyclones occur. The calculated trends for each longitudinal sector in each time series (Fig. 6b) highlight a strong, but not statistically significant increase in the Atlantic region $\left(30^{\circ} \mathrm{W}-20^{\circ} \mathrm{E}\right)$, while a moderate, but statistically significant increase is apparent in the Tasman Sea $\left(150-180^{\circ}\right.$ E) and in the Western Pacific basin $\left(120-60^{\circ} \mathrm{W}\right)$.

When an anticyclone high forms, it blocks the zonal flow, splitting it into two branches and creating anomalous snowfall conditions up- and downstream. Figure 7 depicts the cor-

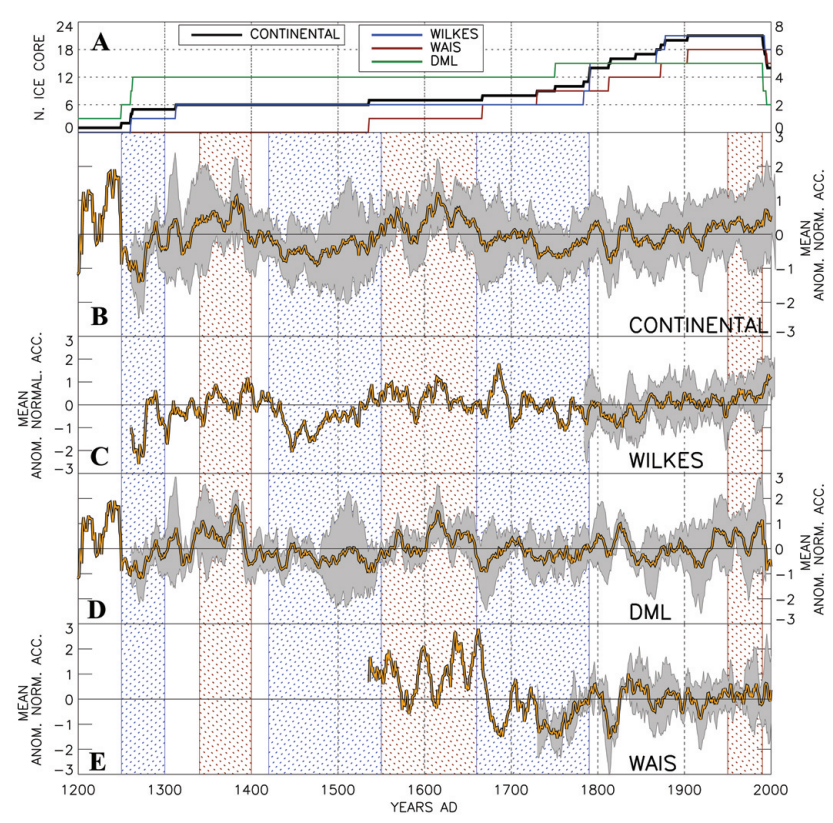

Fig. 4. Mean normalised anomalies of the annually resolved SMB time series at continental and regional scales obtained from the $\Omega_{\text {time }}$ ice core dataset, as described in the text. (A) Number of records from each year in the period from 1200 to 2000 used to calculate the continental (black line, left y-axis), WILKES, DML, and WAIS stacked records (black, blue, green and red lines, respectively, right y-axis). (B) Mean normalised anomalies of the SMB time series at the continental scale. (C) The DML mean normalised anomalies stacked record. (D) The WAIS mean normalised anomalies stacked record. (E) The WAIS mean normalised anomalies stacked record along with the $\pm 1 \sigma$ uncertainty standard deviation (grey-filled contour around each stacked record). The blue- and redfilled rectangles represent periods with negative and positive SMBs at the continental scale, respectively, as described in the text.

relation between the number of blocking events at a specific longitudinal sector and snowfall precipitation. Shifting attention to the continent, it can be noted that positive correlation values are apparent and statistically significant over Eastern Antarctica; anti-correlated areas are found downstream with much lower modulus values that are not statistically significant. Statistically significant anti-correlated areas are apparent only over the oceans downstream the block. Over West Antarctica, the presence of a blocking high causes a larger and more apparent dipole effect in the correlation field. In particular, the positive area values are spread over the Eastern Ross Ice Shelf and part of Marie Byrd Land, while the anticorrelated area encloses only the AP, with an anti-correlation maximum at its base.

\section{Discussion}

Knowledge of the complex mechanisms that control snow accumulation at different time scales is one of the most 


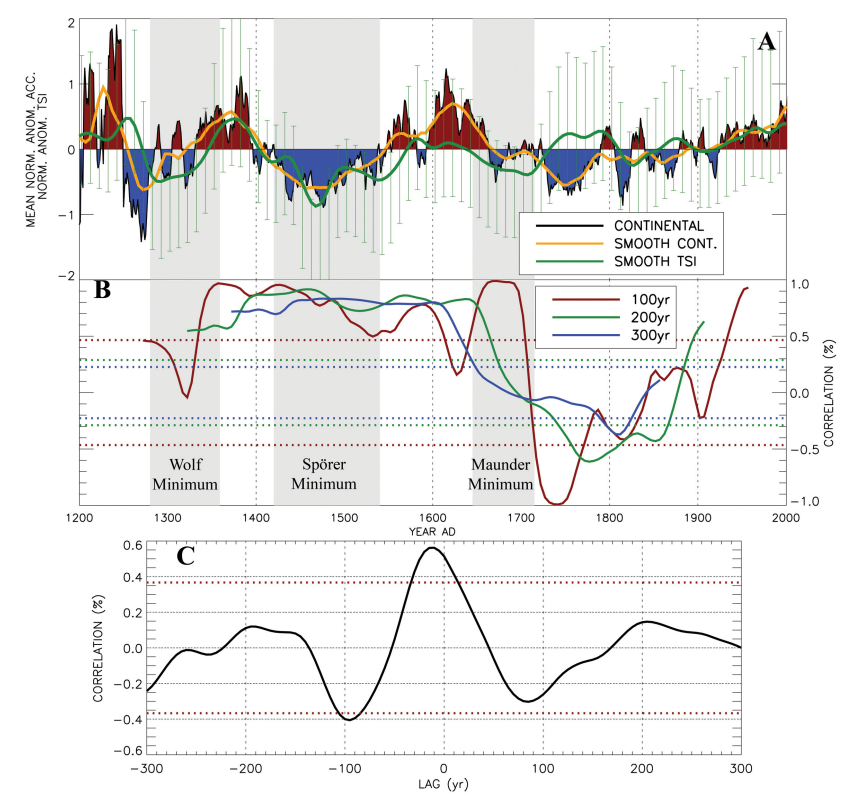

Fig. 5. (A) Mean normalised stacked SMB anomaly time series at the continental scale, calculated as described in the text (black line with positive and negative values filled in with red and blue contours, respectively) and the 40 -yr central running average smoothing (orange line). The green line represents the normalised TSI anomalies, and the corresponding $\pm 1 \sigma$ uncertainties are indicated by the green vertical bars. (B) Running correlations in 100-, 200-, and 300yr time windows (red, green, and blue solid lines, respectively) between the normalised TSI anomaly and the continental accumulation record, smoothed as described in the text. The red, green, and blue dashed lines represent the threshold values corresponding to the $95 \%$ statistically significant level based on a two-tailed Student t-test (100-, 200-, and 300-yr time running windows, respectively). The filled grey areas represent the Wolf, Spörer, and Maunder minimums in solar activity. (C) Correlations at different time lags between the normalised TSI anomaly and the continental accumulation record, smoothed as described in the text. The red line represents the threshold value corresponding to the $95 \%$ statistically significant level based on a two-tailed Student t-test.

important challenges in the field of polar science. Our 800-yr SMB reconstruction reveals a better correlation of accumulation variation with altimetry than with regional basin accumulation. This result is in accordance with the findings of Genthon et al. (2009), who stated that approximately $75 \%$ of the predicted increase in precipitation will occur in the peripheral areas at surface elevations below $2250 \mathrm{~m}$. To explain the different behaviours exhibited between the highaccumulation coastal areas/highest IDEA site and the rest of Antarctica at different (inter-annual to decadal) time scales, we suggest that the higher frequency of blocking-anticyclone events increases the precipitation at coastal sites and leads to the advection of moist air at the highest area of the IDEA site. However, blowing snow and/or erosion have significantly negative impacts on the SMBs of windy sites when kata-

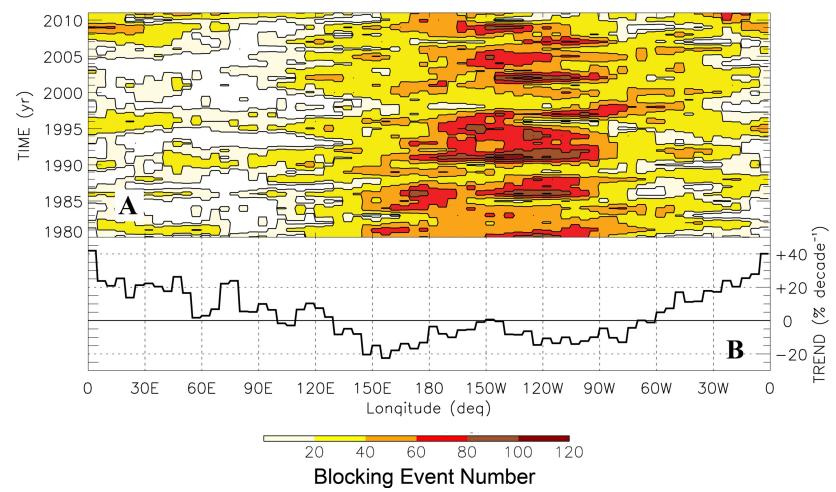

Fig. 6. (A) Contour of the annual number of blocked days for each longitude sector ( $5^{\circ}$ wide) from 1980 to 2011 . Blocked days are calculated from. ECMWF ERA INTERIM Re-Analysis of Geopotential height at a 500-hPa field on a regular grid of $1^{\circ} \times 1^{\circ}$ (Simmons et al., 2006), following the procedure described in Scarchilli et al. (2011). (B) Trend of the annual number of blocked daytime series for each longitude sector $\left(5^{\circ}\right.$ wide), expressed as the ratio between the trend per decade and the average of the time series over the entire period (1980-2011).

batic strong wind events are enhanced by deepening pressure off the coast and increasing pressure inland (Frezzotti et al., 2007).

Snow precipitation in Antarctica is driven by several factors (e.g., atmospheric circulation patterns and ocean surface conditions), which exhibit differences between the coastal and inland plateaus. In the interior of the high plateau $(>2500 \mathrm{~m})$, the majority of precipitation fell in the form of "diamond dust" (ice crystals) from clear skies and accounted for half of the annual total precipitation (Fujita and Abe, 2006). At these sites, it is impossible to determine the annual layer, and the past accumulation rates are believed to be proportionate to temperature reconstructions derived from the stable water isotope composition. In interpretations of the paleo-climate, it is assumed that all changes in the source temperature/location are negligible and that changes in the stable water isotope composition of ice primarily reflect changes in temperature at the ice core site (see Masson-Delmotte et al., 2008). Accordingly, the paleo-accumulation is assumed to be thermodynamically controlled by the change in saturation water vapour pressure at the inversion layer, which is a function of temperature. The stable isotopic composition of snow precipitation $\left(\delta \mathrm{O}^{18} / \delta \mathrm{D}\right)$ is the closest proxy of air temperature. The ratio of heavy $\left(\delta \mathrm{O}^{18}\right)$ to light $\left(\delta \mathrm{O}^{16}\right)$ water molecules in precipitation is influenced by the source temperature, the isotopic composition where the evaporation occurs, the moisture pathway toward the site and the temperature at the site when the precipitation occurs (Masson-Delmotte et al., 2008). The error in the accumulation as determined based on the stable isotope variation is estimated to be as high as $30 \%$ or higher (see Supplement 


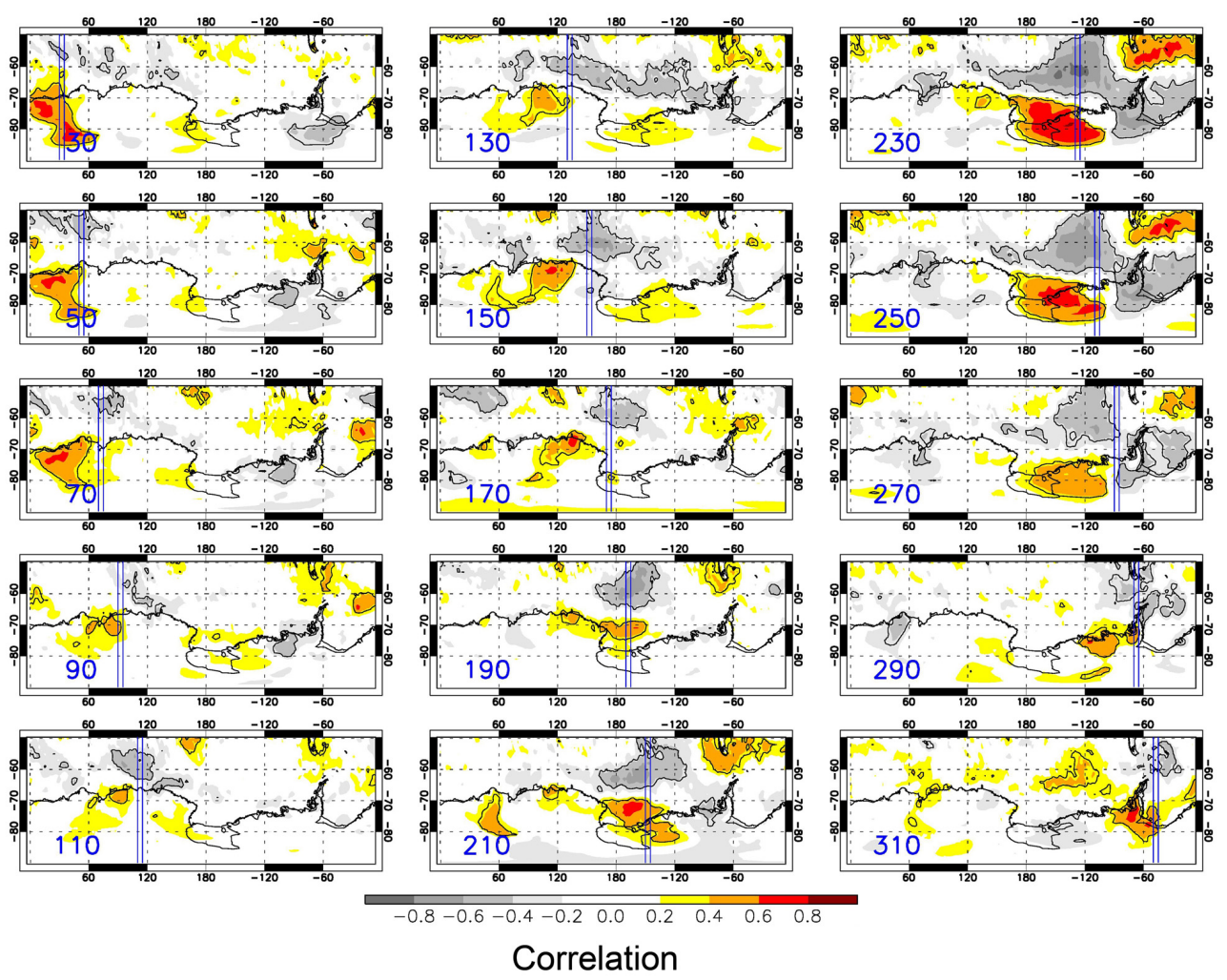

Fig. 7. Spatial correlation between the cumulative annual ERA INTERIM snowfall and cumulative annual blocked days, calculated as in Scarchilli et al. (2011), for different longitudinal sectors (blue vertical lines and numbers represent the sectors involved in the correlation). The black lines enclose correlation values significant larger than $95 \%$.

of EPICA Community Members, 2004; Schwander et al., 2001).

Indeed, the available seasonal to annual $\delta \mathrm{O}^{18} / \delta \mathrm{D}$ ratio and SMB records $\left(>70 \mathrm{~kg} \mathrm{~m}^{-2} \mathrm{yr}^{-1}\right)$ over the last centuries do not demonstrate a clear correlation between a "warm/cold" isotope and "high/low" levels of snow accumulation (e.g., Thompson et al., 1994; Stenni et al., 2002; Oerter et al., 1999; Abram et al., 2011; Fernandoy et al., 2010; Graf et al., 2002; Mulvaney et al., 2002; Divine at al., 2009).

As shown above, the three periods of lowest accumulation (1250-1300, 1420-1550 and 1660-1790) observed revealed in the continental stacked record correspond to periods of low solar activity (Fig. 5a). If a relationship between those two variables is present, it is indirect and almost certainly linked to a teleconnection in the atmospheric circulation forcing through complex feedback. Eichler et al. (2009) analysed the importance of solar forcing based on an isotopic record from continental Siberian Altai and noted the importance of the indirect sun-climate mechanisms involving ocean-induced changes in atmospheric circulation. Several authors have reported a link between the solar minimum and changes in atmospheric circulation, with a shift of the southern westerly wind positions during the past millennia (e.g., Swingedouw et al., 2011; Verschuren et al., 2000; Thresher, 2002;
Varma et al., 2011; Ineson et al., 2011; Martin-Puertas et al., 2012). Delaygue and Bard (2010) noted that the lowest solar activity occurred during the Spörer minimum at the South Pole and Dome Fuji sites based on stacked records of Beryllium $\left({ }^{10} \mathrm{Be}\right)$, a proxy of solar activity. Sachs et al. (2009) provided strong evidence that during the past millennium, the Pacific Inter-tropical Convergence Zone was in its southernmost position during the Spörer minimum. The central tropical Pacific is a critical region with a significant influence on atmospheric circulation in the Southern Hemisphere through the generation and propagation of a large-scale atmospheric wave train during winter (Lachlan-Cope and Connolley, 2006) that can, in turn, enhance/inhibit blocking high phenomena. Tropical climate signals are primarily communicated to Antarctica via the Pacific-South America pattern and the Southern Annular Mode, driven by Rossby wave trains (Fogt and Bromwich, 2006; Schneider et al., 2012). Indeed, over the past $30 \mathrm{yr}$, anomalous sea surface temperatures in the central tropical Pacific have generated an atmospheric Rossby wave response influencing the atmospheric circulation over the Amundsen Sea and causing increased advection of warm air to the WAIS and AP (Ding et al., 2011b).

However, at a shorter time scale, other forcing factors, such as volcanic aerosols and greenhouse gas concentrations, 
have changed over time, and they could be overlapping and obscuring the solar fingerprint. From this perspective, the abrupt decreases in the correlation between TSI and SMB over the running windows can be viewed as the signatures of this obscuring effect on solar forcing. In a recent paper on TSI reconstruction from ice cores and tree rings, Steinhilber et al. (2012) provided evidence for a generally good correlation between solar forcing and the Asian climate. However, they also noted periods without any coherence in which other types of forcing, such as volcanoes and greenhouse gas concentrations (and their corresponding feedback), deeply influenced the climate.

Previous studies have shown a correlation between blocking-anticyclones and snow accumulation in most parts of Antarctica (e.g., Massom et al., 2004; Goodwin et al., 2003; Schlosser et al., 2011; Hirasawa et al., 2000). Snowfall events have been found to be highly episodic; they can occur in connection with (blocking) anticyclones and, correspondingly, amplified Rossby waves, which lead to the advection of warm and moist air from relatively low latitudes. When a blocking event occurs, the moisture-rich air masses in the southern branch of the split flow are forced to be adiabatically uplifted to a colder environment, producing more precipitation than normal over the Antarctic coast upstream of the block. On the other hand, downstream of the block, the anomalous drying effect is primarily observed over the sea in areas of reduced zonal flow, with small and negligible consequences over the Antarctic (Fig. 7). The amount of snowfall associated with blocking conditions can be twice as great at high-accumulation coastal sites (40\% at Law Dome) than at inland sites (20\% at Dome C and Taylor Dome, $25 \%$ at Talos Dome; Scarchilli et al., 2011). Moreover, Sodemann and Stohl (2009) noted that the highest altitudes of the EAIS exhibit mean moisture source latitudes that are further north $\left(45-40^{\circ} \mathrm{S}\right)$ than those of the coastal and slope areas (55$60^{\circ} \mathrm{S}$ ). Finally, the accumulation increase along the IDEA over the last few decades is consistent with the positive trend in the number of blocked days at longitudes between $30^{\circ} \mathrm{W}$ and $60^{\circ} \mathrm{E}$, as well as with the positive effect of blocking events in the longitudinal arc on the precipitation in that area (Fig. 6b and a, respectively).

Wind-driven ablation strongly affects the SMB, and one of the largest areas of uncertainty regarding present and future SMB calculations is the role of wind-driven sublimation. Field and satellite observations demonstrate that wind-driven sublimation rates are lower than $50 \mathrm{~kg} \mathrm{~m}^{-2} \mathrm{yr}^{-1}$ in plateau areas but very large in slope areas (up to $260 \mathrm{~kg} \mathrm{~m}^{-2} \mathrm{yr}^{-1}$ ), accounting for $20-75 \%$ of the precipitation (e.g., Frezzotti et al, 2004, 2007; Eisen et al., 2008; Scarchilli et al., 2010). Scambos et al. (2012) suggested that all of the current SMB models of the EAIS overestimate the mass input to the ice sheet by 46 to $82 \mathrm{Gtyr}^{-1}$ of the total inferred accumulation for the regions above $1500 \mathrm{~m}$ in elevation. This overestimation is primarily due to the weak ability of the atmospheric model to reproduce the high speed of katabatic wind and the correlated wind-driven sublimation. However, based on data obtained from a regional atmospheric climate model, RAMCO 2.1/ANT, with a spatial resolution of approximately $27 \mathrm{~km}$, a recently published paper by Lenaerts et al. (2012a) showed that the inter-annual variability of drifting snow sublimation integrated over the ice sheet is small (approximately $12 \mathrm{Gt} \mathrm{yr}^{-1}$ ) at only approximately $0.5 \%$ of the total accumulation. Conversely, Lenaerts et al. (2012b) demonstrated that the increase in the RAMCO2.1/ANT model resolution from 27 to $5.5 \mathrm{~km}$ can improve the model's ability to forecast the wind speed maxima in Adélie Land. As a result, the SMB exhibits a much greater local spatial variability at a $5.5 \mathrm{~km}$ resolution, an effect controlled by drifting snow erosion, and the blowing snow sublimation is $>100 \mathrm{~kg} \mathrm{~m}^{-2} \mathrm{yr}^{-1}$ in regions with high wind speeds.

Spatial variations in accumulation are well correlated with surface slope changes along the wind direction, and windy areas represent $90 \%$ of the Antarctic surface (Frezzotti et al., 2004). The SMB records with verified reliability are from relatively low wind speed areas and are, therefore, not representative of windy areas such as the coastal and slope confluences areas. Those areas are strongly influenced by wind that erodes snow and blows it toward ocean. On the other hand, the highest IDEA site represents less than a few percentage points of the lowest SMB of the EAIS $\left(<30 \mathrm{~kg} \mathrm{~m}^{-2} \mathrm{yr}^{-1}\right)$, while the region with a SMB $>300 \mathrm{~kg} \mathrm{~m}^{-2} \mathrm{yr}^{-1}$ represents less than $15 \%$ of the area, but more than $25 \%$ of the precipitation occurring over the entire continent.

Turner et al. $(2005,2009)$ reported that all of the continental stations have exhibited a negative trend in mean sea level pressure during the last $50 \mathrm{yr}$, most coastal stations have recorded increasing mean wind speeds in recent decades, and some EAIS and AP sites have exhibited a significant increase in strong wind events during the last $50 \mathrm{yr}$. These changes have been correlated with the shift of Southern Annular Mode (SAM) to a more positive phase (Marshall, 2003). This shift has resulted in a decrease in mean sea level pressure over the Antarctic/Southern Ocean with a consequent increase in the westerly winds over the Southern Ocean. Similarly, Simmonds et al. (2003) noted that the intensity of the mean cyclone activity has increased in the Southern Ocean since the 1990s. Around the slope and coastal area of EAIS, the significant majority of strong wind events are associated with the enhancement of the downslope katabatic flow by broad-scale synoptic circulation involving a deepening of pressure off the coast and an increase in pressure inland (Turner et al., 2009). 


\section{Conclusions}

A total of $67 \mathrm{SMB}$ records from the AIS over the last $800 \mathrm{yr}$ were analysed to assess the temporal variability of accumulation rates. The temporal and spatial variability of the SMB over the previous $800 \mathrm{yr}$ indicates that SMB changes over most of Antarctica are statistically negligible and do not exhibit an overall clear trend. This result is in accordance with the results presented by Monaghan et al. (2006), which demonstrate statistically insignificant changes in the SMB over the past $50 \mathrm{yr}$. However, a clear increase in accumulation of more than $10 \%$ (>300 $\mathrm{kg} \mathrm{m}^{-2} \mathrm{yr}^{-1}$ ) has occurred in highSMB coastal regions and over the highest part of the East Antarctic ice divide since the 1960s. The decadal records of previous centuries show that the observed increase in accumulation is not anomalous at the continental scale, that highaccumulation periods also occurred during the 1370s and 1610 s, and that the current SMB is not significantly different from that over the last $800 \mathrm{yr}$.

The differences in behaviour between the coastal/ice divide sites and the rest of Antarctica could be explained by the higher frequency of blocking anticyclones, which increase precipitation at coastal sites and lead to the advection of moist air at the highest areas, while blowing snow and/or erosion have reduced the SMB at windy sites. Eight hundred years of stacked SMB records mimic the total solar irradiance during the 13th and 18th centuries, suggesting a link between the southern Tropical Pacific and the atmospheric circulation in Antarctica through the generation and propagation of a large-scale atmospheric wave train.

Minor changes in the earth's radiation budget may profoundly affect the atmospheric circulation and SMB of Antarctica. To predict future trends in the ice sheet mass balance, models must reliably reproduce the SMB patterns of the 2000s and the recent past (at the year-long and millennial scales). Future scenarios provided by global climate models suggest that Antarctic snow precipitation should increase in a warming climate but that snow accumulation is primarily driven by atmospheric circulation; these increases could be offset by enhanced loss due to wind blowing ablation.

Acknowledgements. This research was conducted as part of the framework of the Project on Glaciology of the PNRA-MIUR, ice2sea project and contributed to the European Science Foundation (ESF) HOLOCLIP Project. The HOLOCLIP Project, a joint research project of the ESF PolarCLIMATE programme, is funded by national contributions from Italy, France, Germany, Spain, Netherlands, Belgium and the United Kingdom. We acknowledge the ice2sea project, funded by the European Commission's 7th Framework Programme through grant number 226375. This is ice2sea publication 70 and HOLOCLIP publication 15 .

Edited by: E. Larour

\section{References}

Abram, N. J., Thomas, E. R., McConnell, J. R, Mulvaney, R., Bracegirdle, T. J., Sime, L. C., and Aristarain, A. J.: Ice core evidence for a 20th century decline of sea ice in the Bellingshausen Sea, Antarctica, J. Geophys. Res., 115, D23101, doi:10.1029/2010JD014644, 2010.

Abram, N. J., Mulvaney, R., and Arrowsmith, C.: Environmental signals in a highly resolved ice core from James Ross Island, Antarctica, J. Geophys. Res., 116, D20116, doi:10.1029/2011JD016147, 2011.

Anschütz, H., Steinhage, D., O. Eisen, O., Oerter, H., Horwath, M., and Ruth, U.: Small-scale spatio-temporal characteristics of accumulation rates in Western Dronning Maud Land, Antarctica, J. Glaciol., 54, 315-323, 2008.

Anschütz, H., Müller K., Isaksson, E., McConnell, J. R., Fischer, H., Miller, H., Albert, M., and Winther, J.-G.: Revisiting sites of the South Pole Queen Maud Land Traverses in East Antarctica: accumulation data from shallow firn cores, J. Geophys. Res., 114, D24106, doi:10.1029/2009JD012204, 2009.

Anschütz, H., Sinisalo, A., Isaksson, E., McConnell, J. R., Hamran, S.-E., Bisiaux, M. M., Pasteris, D., Neumann, T. A., and Winther, J.-G.: Variation of accumulation rates over the last eight centuries on the East Antarctic Plateau derived from volcanic signals in ice cores, J. Geophys. Res., 116, D20103, doi:10.1029/2011JD015753, 2011.

Aristarain, A. J., Delmas, R. J., and Stievenard, M.: Ice-core study of the link between sea-salt aerosol, sea-ice cover and climate in the Antarctic Peninsula area, Clim. Change, 67, 63-86, 2004.

Banta, J. R., McConnell, J. R., Frey, M. M., Bales, R. C., and Taylor, K.: Spatial and temporal variability in snow accumulation at WAIS Divide over recent centuries, J. Geophys. Res., 113, D23102, doi:10.1029/2008JD010235, 2008.

Castellano, E., Becagli, S., Hansson, M., Hutterli, M., Petit, J. R., Rampino, M. R., Severi, M., Steffensen, J. P., Traversi, R., and Udisti, R.: Holocene volcanic history as recorded in the sulfate stratigraphy of the European Project for Ice Coring in Antarctica Dome C (EDC96) ice core, J. Geophys. Res., 110, D06114, doi:10.1029/2004JD005259, 2005.

Chapman, W. L. and Walsh, J. E.: A synthesis of Antarctic temperature, J. Climate, 20, 4096-4117, 2007.

Cole-Dai, J., Mosley-Thompson, E., Wright, S., and Thompson, L.: A 4100-year record of explosive volcanism from an East Antarctica ice core, J. Geophys. Res., 105, 24431-24441, 2000.

Curran, M. A. J., Van Ommen, T. D., Morgan, V. I, Phillips, K. L., and Palmer, A. S.: Ice core evidence for Antarctic sea ice decline since the 1950s, Science, 302, 1203-1206, 2003.

Delaygue, G. and Bard, E.: An Antarctic view of beryllium-10 and solar activity for the past millennium, Clim. Dynam., 36, 22012218, doi:10.1007/s00382-010-0795-1, 2010.

Ding, M., Xiao, C., Li, Y., Ren, J., Hou, S., Jin, B., and Sun, B.: Spatial variability of surface mass balance along a traverse route from Zhongshan station to Dome A, Antarctica, J. Glaciol., 57, 658-666, doi:10.3189/002214311797409820, 2011a.

Ding, Q., Steig, E. J., Battisti, D. S., and Küttel, M.: Winter warming in West Antarctica caused by central tropical Pacific warming, Nat. Geosc., 4, 398-403, doi:10.1038/ngeo1129, 2011 b.

Divine, D. V., Isaksson, E., Kaczmarska, M., Godtliebsen, F., Oerter, H., Schlosser, E., Johnsen, S. J., van den Broeke, M., and van de Wal, R. S. W.: Tropical Pacific-high latitude 
south Atlantic teleconnections as seen in $\delta 180$ variability in Antarctic coastal ice cores, J. Geophys. Res., 114, D11112, doi:10.1029/2008JD010475, 2009.

Eichler, A., Olivier, S., Henderson, K., Laube, A., Beer, J., Papina, T., Gäggeler, H. W., and Schwikowski, M.: Temperature response in the Altai region lags solar forcing, Geophys. Res. Lett., 36, L01808, doi:10.1029/2008GL035930, 2009.

Eisen, O., Frezzotti, M., Genthon, C., Isaksson, E., Magand, O., Broeke, M. R., Dixon, D. A., Ekaykin, A., Holmlund, P., Kameda, T., Karlöf, L., Kaspari, S., Lipenkov, V. Y., Oerter, H., Takahashi, S., and Vaughan, D. G.: Ground-based measurements of spatial and temporal variability of snow accumulation in East Antarctica, Rev. Geophys. 46, RG2001, doi:10.1029/2006RG000218, 2008.

Ekaykin, A. A., Lipenkov, V. Y., Kuzmina, I., Petit, J. R., MassonDelmotte, V., and Johnsen, S. J.: The changes in isotope composition and accumulation of snow at Vostok station, East Antarctica, over the past 200 years, Ann. Glaciol., 39, 569-575, 2004.

EPICA Community Members: Eight glacial cycles from an Antarctic ice core, Nature, 429, 623-628, 2004.

Fernandoy, F., Meyer, H., Oerter, H., Wilhelms, F., Graf, W., and Schwander, J.: Temporal and spatial variation of stable-isotope ratios and accumulation rates in the hinterland of Neumayer station, East Antarctica, J. Glaciol., 56, 673-687, 2010.

Fogt, R. L., Bromwich, D. H., and Hines, K. M.: Decadal variability of the ENSO teleconnection to the high latitude South Pacific governed by coupling with the Southern Annular Mode, J. Clim., 19, 979-997, 2006.

Frezzotti, M., Bitelli, G., de Michelis, P., Deponti, A., Forieri, A., Gandolfi, S., Maggi, V., Mancini, F., Rémy, F., Tabacco, I. E., Urbini, S., Vittuari, L., and Zirizzotti, A.: Geophysical survey at Talos Dome (East Antarctica): the search for a new deep-drilling site, Ann. Glaciol., 39, 423-432, 2004.

Frezzotti, M., Pourchet, M., Flora, O., Gandolfi, S., Gay, M., Urbini, S., Vincent, C., Becagli, S., Gragnani, R., Proposito, M., Severi, M., Traversi, R., Udisti, R., and Fily, M.: Spatial and temporal variability of snow accumulation in East Antarctica from traverse data, J. Glaciol., 51, 113-124, 2005.

Frezzotti, M., Urbini, S., Proposito, M., Scarchilli, C., and Gandolfi, S.: Spatial and temporal variability of surface mass balance near Talos Dome, East Antarctica, J. Geophys. Res., 112, F02032, doi:10.1029/2006JF000638, 2007.

Fujita, K. and Abe, O.: Stable isotopes in daily precipitation at Dome Fuji, East Antarctica, Geophys. Res. Lett., 33, L18503, doi:10.1029/2006GL026936, 2006.

Fujita, S., Holmlund, P., Andersson, I., Brown, I., Enomoto, H., Fujii, Y., Fujita, K., Fukui, K., Furukawa, T., Hansson, M., Hara, K., Hoshina, Y., Igarashi, M., Iizuka, Y., Imura, S., Ingvander, S., Karlin, T., Motoyama, H., Nakazawa, F., Oerter, H., Sjöberg, L. E., Sugiyama, S., Surdyk, S., Ström, J., Uemura, R., and Wilhelms, F.: Spatial and temporal variability of snow accumulation rate on the East Antarctic ice divide between Dome Fuji and EPICA DML, The Cryosphere, 5, 1057-1081, doi:10.5194/tc-51057-2011, 2011.

Genthon, C., Krinner, G., and Castebrunet, H.: Antarctic precipitation and climate change prediction: horizontal resolution and margin vs plateau issues, Ann. Glaciol., 50, 55-60, 2009.

Gibson, T. T.: Atmospheric blocking in the Southern Hemisphere 1982-1992. Proc. APOC and AMOS Joint Conf., Lorne, Aus- tralia, Australian Meteorological and Oceanographic Society, 40, 1995.

Goodwin, I., de Angelis, M., Pook, M., and Young, N. W.: Snow accumulation variability in Wilkes Land, East Antarctica, and the relationship to atmospheric ridging in the $130^{\circ}-170^{\circ} \mathrm{E}$ since 1930, J. Geophys. Res., 108, 4673, doi:10.1029/2002JD002995, 2003.

Graf, W., Oerter, H., Reinwarth, O., Stichler, W., Wilhelms, F., Miller, H., and Mulvaney, R.: Stable isotope records from Dronning Maud Land, Antarctica, Ann. Glaciol., 35, 195-201, 2002.

Gregory, J. M. and Huybrechts, P.: Ice-sheet contributions to future sea-level change, Philos. Trans. R. Soc. A, 364, 1709-1731, doi:10.1098/rsta.2006.1796, 2006.

Hamilton, G. S.: Topographic control of regional accumulation rate variability at South Pole and implications for ice-core interpretation, Ann. Glaciol., 39, 214-218, doi:10.3189/172756404781814050, 2004.

Hirasawa, N., Nakamura, H., and Yamanouchi, T.: Abrupt changes in meteorological conditions observed at an inland Antarctic Station in association with wintertime blocking, Geophys. Res. Lett., 27, 1911-1914, doi:10.1029/1999GL011039, 2000.

Hofstede, C. M, van de Wal, R. S. W., Kaspers, K. A., van den Broeke, M. R., Karlöf, L., Winther, J. G., Isaksson, E., Lappegard, G., Mulvaney, R., Oerther, H., and Wilhelms, F.: Firn accumulation records for the past 1000 years on the basis of dielectric profiling of six firn cores from Dronning Maud Land, Antarctica, J. Glaciol., 50, 279-291, 2004.

Hou, S. G., Li, Y. S., Xiao, C. D., and Ren, J.: Recent accumulation rate at Dome A, Antarctica, Chin. Sci. Bull., 52, 428-431, 2007.

Hou, S. G., Li, Y. S., Xiao, C. D., Pang, H. X., and Xu, J. Z.: Preliminary results of the close-off depth and the stable isotopic records along a $109.91 \mathrm{~m}$ ice core from Dome A, Antarctica, Sci, China Ser. D-Earth Sci., 52, 1502-1509, doi:10.1007/s11430009-0039-6, 2009.

Igarashi, M., Nakai, Y., Motizuki, Y., Takahashi, K., Motoyama, H., and Makishima, K.: Dating of the Dome Fuji shallow ice core based on a record of volcanic eruptions from AD 1260 to AD 2001, Polar Sci., 5, 411-420, doi:10.1016/j.polar.2011.08.001, 2011.

Ineson, S., Scaife, A., Knight, J. R., Manners, J. C., Dunstone, N. J., Gray, L. J., and Haigh, J. D.: Solar forcing of winter climate variability in the Norther Hemisphere, Nature Geosci., 4, 753757, 2011.

Isaksson, E., van den Broeke, M., Winther, J. G., Karlöf, L., Pinglot, J., and Gundestrup, N.: Accumulation and proxy-temperature variability in Dronning Maud Land, Antarctica, determined from shallow firn cores, Ann. Glaciol., 29, 17-22, 1999.

ISMASS Committee: Recommendations for the collection and synthesis of Antarctic Ice Sheet mass balance data, Global Planet. Change, 42, 1-15, doi:10.1016/j.gloplacha.2003.11.008, 2004.

Jiang, S., Cole-Dai, J., Li, Y., Ferris, D.G., Ma, H., An, C., Shi, G., and Sun, B.: A detailed 2840 year record of explosive volcanism in a shallow ice core from Dome A, East Antarctica, J. Glaciol., 58, 65-75, doi:10.3189/2012JoG11J138, 2012.

Kaczmarska, M., Isaksson, E., Karlöf, K., Winther, J-G, Kohler, J., Godtliebsen, F., Ringstad Olsen, L., Hofstede, C. M., van den Broeke, M. R., Van De Wal, R. S. W., and Gundestrup, N.: Accumulation variability derived from an ice core from coastal Dronning Maud Land, Antarctica, Ann. Glaciol., 39, 339-345, 2004. 
Kameda, T., Motoyama, H., Fujita, S., and Takahashi S.: Temporal and spatial variability of surface mass balance at Dome Fuji, East Antarctica, by the stake method from 1995 to 2006, J. Glaciol., 54, 107-116, doi:10.3189/002214308784409062, 2008.

Karlöf, L. Winther, J.-G., Isaksson, E., Kohler, J., Pinglot, J. F., Wilhelms, F., Hansson, M., Holmlund, P., Nyman, M., Pettersson, R., Stenberg, M., Thomassen, M. P. A., van der Veen, C., and van de Wal, R. S. W.: A 1500 year record of accumulation at Amundsenisen, western Dronning Maud Land, Antarctica, derived from electrical and radioactive measurements on a $120 \mathrm{~m}$ ice core, J. Geophys. Res., 105, 12471-12483, 2000.

Karlöf, L., Isakson, E., Winther, J. G., Gundestrup, N., Meijer, H. A. J., Mulvaney, R., Pourcher, M., Hofstede, C., Lappegard, G., Petterson, R., van den Broecke, M. R., and van de Wal, R. S. W.: Accumulation variability over a small area in east Dronning Maud Land, Antarctica, as determined from shallow firn cores and snow pits: some implications for ice, J. Glaciol., 51, 343352, doi:10.3189/172756505781829232, 2005.

Kaspari, S., Mayewski, P. A., Dixon, D. A., Spikes, V. B., Sneed, S. B., Handley, M. J., and Hamilton, G. S.: Climate variability in west Antarctica derived from annual accumulation-rate records from ITASE firn/ice cores, Ann. Glaciol., 39, 585-594, doi:10.3189/172756404781814447, 2004.

Krinner, G., Magand, O., Simmonds, I., Genthon, C., and Dufresne, J. L.: Simulated Antarctic precipitation and surface mass balance at the end of the 20th and 21th centuries, Clim. Dynam. 28, 215230, doi:10.1007/s00382-006-0177-x, 2007.

Lachlan-Cope, T. and Connolley, W.: Teleconnections between the tropical Pacific and the Amundsen-Bellinghausens Sea: role of the El Niño/Southern Oscillation, J. Geophys. Res., 111, D23101, doi:10.1029/2005JD006386, 2006.

Lenaerts, J. T. M., van den Broeke, M. R., van den Berg, W. J., van Meijgaard, E., and Munneke, P. K.: A new, high resolution surface mass balance map of Antarctica (1979-2010) based on regional climate modeling, Geophys. Res. Lett., 39, L04501, doi:10.1029/2011GL050713, 2012a.

Lenaerts, J. T. M., van den Broeke, M. R., Scarchilli, C., and Agosta, C.: Impact of model resolution on simulated wind, drifting snow and surface mass balance in Adélie Land, East Antarctica, J. Glaciol., 58, 821-829, doi:10.3189/2012JoG12J020, 2012b.

Magand, O., Frezzotti, M., Pourchet, M., Stenni, B., Genoni, L., and Fily, M.: Climate variability along latitudinal and longitudinal transects in east Antarctica, Ann. Glaciol., 39, 351-358, doi:10.3189/172756404781813961, 2004.

Magand, O., Genthon, C., Fily, M., Krinner, G., Picard, G., Frezzotti, M., and Ekaykin, A. A.: An up-to-date quality-controlled surface mass balance data set for the $90^{\circ}-180^{\circ} \mathrm{E}$ Antarctica sector and 1950-2005 period, J. Geophys. Res., 112, D12106, doi:10.1029/2006JD007691, 2007.

Marques, R. F. C. and Rao V. B: Interannual variations of blocking in the Southern Hemisphere and their energetics, J. Geophys. Res., 105, 4625-4636, 2000.

Marshall, G. J.: Trends in the Southern Annular Mode from observations and reanalyses, J. Climate, 16, 4134-4143, doi:10.1175/1520-0442(2003)016<4134:TITSAM > 2.0.CO;2, 2003.

Marshall, G. J.: On the annual and semi-annual cycles of precipitation across Antarctica, Int. J. Climatatol., 29, 2298-2308, doi:10.1002/joc.1810, 2009.
Martín-Puertas, C., Matthes, K., Brauer, A., Muscheler, R., Hansen, F., Petrick, C., Aldahan, A., Possnert, G., and van Geel, B.: Regional atmospheric circulation shifts induced by a grand solar minimum, Nature, Geosc., 5, 397-401, 2012.

Massom, R. A., Pook, M. J., Comiso, J. C., Adams, N., Turner, J., Lachlan-Cope, T., and Gibson, T.: Precipitation over the interior East Antarctic Ice Sheet related to midlatitude blocking-high activity, J. Climate, 17, 1914-1928, 2004.

Masson-Delmotte, V., Hou, S., Ekaykin, A., Jouzel, J., Aristarain, A., Bernardo, R. T., Bromwich, D., Cattani, O., Delmotte, M., Falourd, S., Frezzotti, M., Gallée, H., Genoni, L., Isaksson, E., Landais, A., Helsen, M. M., Hoffmann, G., Lopez, J., Morgan, V., Motoyama, H., Noone, D., Oerter, H., Petit, J. R., Royer, A., Uemura, R., Schmidt, G. A., Schlosser, E.,. Simöes, J. C., Steig, E. J., Stenni, B., Stievenard, M., van den Broeke, M. R., van de Wal, R. S. W., van de Berg, W. J., Vimeux, F., and White, J. W. C.: A review of Antarctic surface snow isotopic composition: Observations, atmospheric circulation, and isotopic modeling, $\mathrm{J}$. Climate, 21, 3359-3387, doi:10.1175/2007JCLI2139.1, 2008

McConnell, J. R., Bales, R. C., and Davis, D. R.: Recent intraannual snow accumulation at South Pole: implications for ice core interpretation, J. Geophys. Res., 102, 21947-21954, 1997.

Monaghan, A. J., Bromwich, D. H., Fogt, R. L., Wang, S., Mayewski, P. A., Dixon, D. A., Ekaykin, A., Frezzotti, M., Goodwin, I., Isaksson, E., Kaspari, S. D., Morgan, V. I., Oerter, H., Van Ommen, T. D., van der Veen, C. J., and Wen, J.: Insignificant change in Antarctic snowfall since the International Geophysical Year, Science, 313, 827-831, doi:10.1126/science.1128243, 2006.

Monaghan, A. J., Bromwich, D. H., and Schneider, D. P.: Twentieth century Antarctic air temperature and snowfall simulations by IPCC climate models, Geophys. Res. Lett., 35, L07502, doi:10.1029/2007GL032630, 2008.

Moore, J. C., Narita, H., and Maeno, N.: A continuous 770-year record of volcanic activity from East Antarctica, J. Geophys. Res., 96, 17353-17359, 1991.

Morgan, V. I., Goodwin, I. D., Etheridge, D. M., and Wookey, C. W.: Evidence for increased accumulation in Antarctica, Nature, 354, 58-60, 1991.

Mosley-Thompson, E., Paskievitch, J. F., Gow, A. J., and Thompson, L. G.: Late 20th century increase in South Pole snow accumulation, J. Geophys. Res., 104, 3877-3886, 1999.

Mulvaney, R., Oerter, H., Peel, D. A., Graf, W., Arrowsmith, C., Pasteur, E. C., Knight, B., Littot, G. C., and Miners, W. D: 1000-year ice core records from Berkner Island, Antarctic, Ann. Glaciol., 35, 45-51, doi:10.3189/172756402781817176, 2002.

Nishio, F., Furukawa, T., Hashida, G., Igarashi, M., Kameda, T., Kohno, M., Motoyama, H., Naoki, K., Satow, K., Suzuki, K., Morimasa, T., Toyama, Y., Yamada, T., and Watanabe, O.: Annual-layer determinations and 167 year records of past climate of $\mathrm{H} 72$ ice core in east Dronning Maud Land, Antarctica, Ann. Glaciol., 35, 471-479, 2002.

Noone, D., Turner, J., and Mulvaney, R.: Atmospheric signals and characteristics of accumulation in Dronning Maud Land, Antarctica, J. Geophys. Res., 104, 19191-19211, doi:10.1029/1999JD900376, 1999.

Oerter, H., Graf, W., Wilhelms, F., Minikin, A., and Miller, H.: Accumulation studies on Amundsenisen, Dronning Maud Land, by means of tritium, DEP and stable isotope measurements: first re- 
sults from the 1995/96 and 1996/97 field seasons, Ann. Glaciol., 29, 1-9, doi:10.3189/172756499781820914, 1999.

Oerter, H., Wilhelms, F., Jung-Rothenhausler, F., Goktas, F., Miller, H., Graf, W., and Sommer, S.: Accumulation rates in Dronning Maud Land as revealed by DEP measurements at shallow firn cores, Ann. Glaciol., 30, 27-34, 2000.

Pritchard, H. D., Arthern, R. J., Vaughan, D. G., and Edwards, L. A.: Extensive dynamic thinning on the margins of the Greenland and Antarctic ice sheets, Nature, 461, 971-975, 2009.

Raymond, C., Weertman, B., Thompson, L., Mosley-Thompson, E., Peel, D., and Mulvaney, R.: Geometry, motion and balance of Dyer Plateau, Antarctica, J. Glaciol., 42, 510-518, 1996.

Ren, J., Qin, D., and Allison, I.: Variations of snow accumulation and temperature over past decades in the Lambert Glacier basin, East Antarctica, Ann. Glaciol., 29, 29-32, 1999.

Ren, J., Li, C., Hou, S., Xiao, C., Qin, D., Li, Y., and Ding, M.: A 2680 year volcanic record from the DT-401 East Antarctic ice core, J. Geophys. Res., 115, D11301, doi:10.1029/2009JD012892, 2010.

Renwick, J. A.: ENSO-related variability in the frequency of South Pacific blocking, Mon. Weather Rev., 144, 3117-3123, 1998.

Rignot, E., Bamber, J. L., Van den Broeke, M. R., Davis, C., Li, Y., Van de Berg, W. J., and Van Meijgaard, E.: Recent Antarctic ice mass loss from radar interferometry and regional climate modelling, Nat. Geosc., 1, 106-110, doi:10.1038/ngeo102, 2008.

Ruth, U., Wagenbach, D., Mulvaney, R., Oerter, H., Graf, W., Pulz, H., and Littot, G.: Comprehensive 1000 year climate history from an intermediate depth ice core from the south dome of Berkner Island, Antarctica: methods, dating and first results, Ann. Glaciol., 39, 146-154, 2004.

Sachs, J. P., Sachse, D., Smittenberg, R. H., Zhang, Z., Battisti, D. S., and Golubic, S.: Southward movement of the Pacific intertropical convergence zone AD 1400-1850, Nat. Geosc., 2, 519-525, doi:10.1038/NGEO554, 2009.

Scambos, T. A., Frezzotti, M., Haran, T., Bohlander, J., Lenaerts, J. T. M., van den Broeke, M. R., Jezek, K., Long, D., Urbini, S., Farness, K., Neumann, T., Albert, M., and Winther, J.-G.: Extent of low-accumulation 'wind glaze' areas on the East Antarctic Plateau: implications for continental ice mass balance, J. Glaciol., 58, 633-647, doi:10.3189/2012JoG11J232, 2012.

Scarchilli, C., Frezzotti, M., Grigioni, P., De Silvestri, L., Agnoletto, L., and Dolci, S.: Extraordinary blowing snow transport events in East Antarctica, Clim. Dynam., 34, 1195-1206, doi:10.1007/s00382-009-0601-0, 2010.

Scarchilli, C., Frezzotti, M., and Ruti, P. M.: Snow precipitation at four ice core sites in East Antarctica: provenance, seasonality and blocking factors, Clim. Dynam., 37, 2107-2125, doi:10.1007/s00382-010-0946-4, 2011.

Schneider, D. P., Okumura, Y., and Deser, C.: Observed antarctic interannual climate variability and tropical linkages, J. Climate, 25, 4048-4066, doi:10.1175/JCLI-D-11-00273.1, 2012.

Schlosser, E. and Oerter, H.: Shallow firn cores from Neumayer, Ekströmisen - A comparison of accumulation rates, and stable isotope ratios, Ann. Glaciol., 35, 91-96, 2002.

Schlosser, E., Powers, J. G., Duda, M. G., and Manning, K. W.: Interaction between Antarctic sea ice and synoptic activity in the circumpolar trough - implications for ice core interpretation, Ann. Glaciol., 52, 9-17, 2011.
Schwander, J., Jouzel, J., Hammer, C. U., Petit, J. R., Udisti, R., and Wolf, E.: A tentative chronology for the EPICA Dome Concordia ice core, Geophys. Res. Lett., 28, 4243-4246, 2001.

Schwartz, S. E.: Heat capacity, time constant, and sensitivity of Earth's climate system, J. Geophys. Res., 112, D24S05, doi:10.1029/2007JD008746, 2007.

Simmonds, I., Keay, K., and Lim, E. P.: Synoptic activity in the seas around Antarctica, Mon. Weather Rev., 131, 272-288, 2003.

Simmons, A., Uppala, D. D., and Kobayashi, S. : ERA-interim: new ECMWF reanalysis product from 1989 onwards, ECMWF Newslett, 100, 25-35, 2006.

Sodemann, H. and Stohl, A.: Asymmetries in the moisture origin of Antarctic precipitation, Geophys. Res. Lett., 36, L22803, doi:10.1029/2009GL040242, 2009.

Sommer, S., Appenzeller, C., Röthlisberger, R., Hutterli, M. A., Stauffer, B., Wagenbach, D., Oerter, H., Wilhelms, F., Miller, H., and Mulvaney, R.: Glacio-chemical study spanning the past $2 \mathrm{kyr}$ on three ice cores from Dronning Maud Land, Antarctica 1. Annually resolved accumulation rates, J. Geophys. Res., 105, 29411-29421, doi:10.1029/2000JD900449, 2000.

Spikes, V. B., Hamilton, G. S., Arcone, S. A., Kaspari, S., and Mayewski, P. A.: Variability in accumulation rates from GPR profiling on the West Antarctic plateau, Ann. Glaciol., 39, 238244, 2004.

Steig, E. J., Schneider, D. P., Rutherford, S. D., Mann, M. E., Comiso, J. C., and Shindell, D. T.: Warming of the Antarctic ice-sheet surface since the 1957 International Geophysical Year, Nature, 457, 459-462, doi:10.1038/nature07669, 2009.

Steinhilber, F., Beer, J., and Frohlich, C.: Total solar irradiance during the Holocene, Geophys. Res. Lett., 36, L19704, doi:10.1029/2009GL040142, 2009.

Steinhilber, F., Abreua, J. A., Beera, J., Brunnera, I., Christlb, M., Fischerc, H., Heikkiläd, U., Kubikb, W., Manna, M., McCrackene, K. G., Millerf, H., Miyaharag, H., Oerter, H., and Wilhelmsf, F.: 9,400 years of cosmic radiation and solar activity from ice cores and tree rings, P. Natl. Acad. Sci., 109, 59675971, doi:10.1073/pnas.1118965109, 2012.

Stenni, B., Caprioli, R., Cimmino, L., Cremisini, C., Flora, O., Gragnani, R., Longinelli, A., Maggi, V., and Torcini, S.: 200 years of isotope and chemical records in a firn core from Hercules Neve, northern Victoria Land, Antarctica, Ann. Glaciol., 29, 106-112, 1999.

Stenni, B., Proposito, M., Gragnani, R., Flora, O., Jouzel, J., Falourd, S., and Frezzotti, M.: Eight centuries of volcanic signal and climate change at Talos Dome (East Antarctica), J. Geophys. Res., 107, 4076, doi:10.1029/2000JD000317, 2002.

Swingedouw, D., Terray, L., Cassou, C., Voldoire, A., Salas-Mélia, D., and Servonnat, J.: Natural forcing of climate during the last millenium: fingerprint of solar variability, Clim Dyn., 36, 13491364, 2011.

Takahashi, H., Yokoyama, T., Igarashi, M., Motoyama, H., and Suzuki, K.: Resolution of environmental variation by detail analysis of YM85 shallow ice core in Antarctica, Bull. Glaciol. Res., 27, 16-23, 2009.

Thomas, E. R., Marshall, G. J., and McConnell, J. R.: A doubling in snow accumulation in the western Antarctic Peninsula since 1850, Geophys. Res. Lett., 35, L01706, doi:10.1029/2007GL032529, 2008. 
Thompson, L. G., Peel, D. A., Mosley-Thompson, E., Mulvaney, R., Dai, J., Lin, P. N., Davis, M. E., and Raymond, C. F.: Climate since A.D. 1510 on Dyer Plateau, Antarctic Peninsula: evidence for recent climate change, Ann. Glaciol., 20, 420-426, 1994.

Thresher, R. E.: Solar correlates of Southern Hemisphere midLatitude climate variability, Int. J. Climatol., 22, 901-915, 2002.

Tibaldi, S., Tosi, E., Navarra, A., and Pedulli, L.: Northern and Southern Hemisphere seasonal variability of blocking frequency and predictability, Mon. Weather Rev., 122, 1971-2003, 1994.

Turner, J., Colwell, S. R., Marshall, G. J., Lachlan-Cope, T. A., Carleton, A. M., Jones, P. D., Lagun, V., Reid, P. A., and Iagovkina, S.: Antarctic climate change during the last 50 years, Int. J. Climatol., 25, 279-294, 2005.

Turner, J., Lachlan-Cope, T. A., Colwell, S., Marshall, G. J., and Connolley, W. M.: Significant warming of the Antarctic winter troposphere, Science, 311, 1914-1917, doi:10.1126/science.1121652, 2006.

Turner, J., Chenoli, S. N., Abu Samah, A., Marshall, G., Phillips, T., and Orr, A.: Strong wind events in the Antarctic, J. Geophys. Res., 114, D18103, doi:10.1029/2008JD011642, 2009.

Uotila, P., Lynch, A. H., Cassano, J. J., and Cullather, R. I.: Changes in Antarctic net precipitation in the 21 st century based on Intergovernmental Panel on Climate Change (IPCC) model scenarios, J. Geophys. Res., 112, D10107, doi:10.1029/2006JD007482, 2007.

Urbini, S., Frezzotti, M., Gandolfi, S., Vincent, C., Scarchilli, C., Vittuari, L., and Fily, M.: Historical behaviour of Dome C and Talos Dome (East Antarctica) revealed by snow accumulation and ice velocity measurements, Global Planet. Changes, 60, 576588, doi:10.1016/j.gloplacha.2007.08.002, 2008.

van den Broeke, M. R., Bamber, J., Lenaerts, J., and Rignot, E.: Ice sheet and sea sevel: thinking outside the box, Surv. Geophys., 32, 495-505, doi:10.1007/s10712-011-9137-z, 2011. van der Veen, C. J., Mosley-Thompson, E., Gow, A. J., and Mark, B. G.: Accumulation at South Pole: comparison of two 900-year records, J. Geophys. Res., 104, 31067-31076, 1999a.

van der Veen, C. J., Whillans, I. M., and Gow, A. J.: On the frequency distribution of net annual snow accumulation at the South Pole, Geophys. Res. Lett., 26, 239-242, 1999 b.

van Ommen, T. D. and Morgan, V.: Snowfall increase in coastal East Antarctica linked with southwest Western Australian drought, Nat. Geosci., 3, 267-272, doi:10.1038/ngeo761, 2010.

Varma, V., Prange, M., Lamy, F., Merkel, U., and Schulz, M.: Solarforced shifts of the Southern Hemisphere Westerlies during the Holocene, Clim. Past, 7, 339-347, doi:10.5194/cp-7-339-2011, 2011.

Velicogna, I.: Increasing rates of ice mass loss from the Greenland and Antarctic ice sheets revealed by GRACE, Geophys. Res. Lett., 36, L19503, doi:10.1029/2009GL040222, 2009.

Verschuren, D., Laird, K. R., and Cumming, B. F.: Rainfall and drought in equatorial east Africa during the past 1,100 years, Nature, 403, 410-414, 2000.

Xiao, C., Mayewski, P. A., Qin, D., Li, Z., Zhang, M., and Yan, Y.: Sea level pressure variability over the southern Indian Ocean inferred from a glaciochemical record in Princess Elizabeth Land, east Antarctica, J. Geophys. Res., 109, D16101, doi:10.1029/2003JD004065, 2004.

Zhang, M., Li, Z., Ren, J., Xiao, C., Qin, D., Kang, J., and Li, J.: 250 years of accumulation, oxygen isotope and chemical records in a firn core from Princess Elizabeth Land, East Antarctica, J. Geogr. Sci., 16, 23-33, doi:10.1007/s11442-006-0103-5, 2006. 